e-makâlât Mezhep Araştırmaları, VII/2 (Güz 2014), ss. 25-70.

ISSN 1309-5803 | www.emakalat.com

\title{
İSLÂM DÜŞÜNCESİNDE İSBÂT-I VÂCİB PROBLEMİ: CELÂLEDDÎN ED-DEVVÂNî'NİN MESELEYE YAKLAŞIMI VE KATKISI
}

\author{
Hatice TOKSÖZ*
}

Öz

İslâm entelektüel geleneğinde isbât-1 vâcib problemi ile ilgili XII. yüzyıldan itibaren müstakil olarak eserler yazılmiștir. $\mathrm{Bu}$ metinlerden ikisi de Celâleddîn ed-Devvânî'nin (ö. 908/ 1502) Risâletü İsbâti'l-vâcibi'l-kadîme ve Risâletü İsbâti'l-vâcibi'l-cedîde adlı eserleridir. Devvânî, Risâletü İsbâti'lvâcibi'l-kadîme'de isbât-1 vâcib ile ilgili hem imkân hem de hudûs delillerini birlikte kullanmıștır. Ayrıca devr ve teselsül konusunu incelemiş ve illetlerin teselsülünün iptaliyle ilgili burhân-1 tatbîk, burhân-1 müzâyefe ve burhân-1 arşî olmak üzere birtakım burhanlar getirmiștir. Bu çalıșmanın temel metni olan Risâletü İsbâti'lvâcibi'l-cedîde adlı eserinde ise Allah'ın varlığının ve birliğinin isbât1, zat-sıfat ilişkisi ve Allah'ın sıfatları ve âlemin mükemmelliği düșüncesinden hareketle Allah'ın cömertliği (cûd) ve hikmeti konularını ele almaktadır. Zât-sıfat ilişkisinde, Allah'ın sıfatlarını zâtının aynı olduğunu söyleyen Devvânî, âlemde çok mükemmel bir düzen olduğunu ifade etmiştir. Ona göre âlemin bu harikulade mükemmelliğinin sebebi de varlığında hiçbir sebebe muhtac olmayan, en yetkin varlık olan Vâcibü'l-Vücûd'dur.

Anahtar kelimeler: Celâleddîn edDevvânî, İsbât-1 Vâcib, Vücûd, Vâcibü'l-Vücûd, Mümkün, Mârifetullah, İllet.
Abstract

The Problem of Demonstration of Necessary Being in Islamic Thought: The Approach and Contribution of Jalaleddin Davani to the Problem

In the intellectual tradition of Muslim thinkers, self contained works were written about the problem of demonstration of necessary being (isbat al-Wajib) after 12th century. Both of the outstanding books on the problem from that time are books of Jalaladdin Dawani (d.908/1502) named as Risâletü İsbâti'lvâcibi'l-kadîme and Risâletü İsbâti'l-vâcibi'lcedîde. In the book, Risâletü İsbâti'l-vâcibi'tkadime, Jalaladdin Dawani uses both the evidence of possibility and the evidence of creation (hudus). Moreover, he deals with the issue of circularity (dawr) and backward chain (teselsul) in terms of argumentation and brings about some types of demonstration to cancel the backward chain such as burhân-1 tatbîk, burhân-1 müzâyefe and burhân-1 arşî. In the book, Risâletü İsbâti'l-vâcibi'l-cedî̀de which is the basic of that work, Dawani discusses about some topics such as the evidence of existence and unity of God, the relation between essence and attributes of God, the attributions of God, and the generosity of God (cûd) in relation with the perfectness of the universe, and the wisdom of God. Accepting as one or the same the essence and attributions of God, Dawani accepts that there is a perfect order in the universe. According to Dawani, the perfect order of the universe stems from wajib al-wujud, the authority of asset or God.

Keywords: Jalaladdin Dawani, Isbat al-Wajib, Being, Necessary Being, Possibility, Knowledge of God, Cause.

* $\quad$ Yrd. Doç. Dr., SDÜ İlahiyat Fakültesi İslâm Felsefesi Öğretim Üyesi. 


\section{Giriş}

İsbât-1 vâcib probleminin İslâm entelektüel geleneğinde Gazzâlî öncesi dönemde genel olarak metafizik ile ilgili konular içinde incelendiği, Gazzâlî sonrası dönemde ise kelâm ve felsefenin mezcedilerek telif edilen önemli metinlerinde hem nazar bahsinde mârifetullah hakkında akıl yürütme başlığı altında hem de ilâhiyyât bölümlerinde Allah'in varlığının isbâtı şeklinde tartışıldığı görülmektedir. Özellikle XII. yüzyıldan itibaren müstakil olarak isbât-1 vâcibe ilişkin eserlerin yazılması ile birlikte, İslâm düşüncesinde zengin bir literatür ortaya çıkmıştır. ${ }^{1}$ Söz konusu literatürde öne çıkan önemli metinlerden biri de Celâleddîn ed-Devvânî’nin (ö.908/1502) Risâletü İsbâti'l-vâcibi'l-cedîde ${ }^{2}$ adlı eseridir.

Bu risaleden önce Devvânî, gençliğinde Risâletü İsbâti'l-vâcibi'lkadîme adlı eserini telif etmiştir. Burada Devvânî, isbât-1 vâcib konusunda kelamcılar ve filozoflar tarafından ileri sürülen çeşitli burhanları ele almıştır. İleri yaşlarında yazdığı Risâletü İsbati'l-vâcibi'lcedîde'de ise başta mârifetullah olmak üzere, evreni okuma biçimlerinden hareketle Allah'ın varlığının ve birliğinin isbatı, Allah'ın sıfatları, bu sıfatların âleme yansıması ve Allah-âlem ilişkisi bağlamında âlemin mükemmelliğini incelemiştir. Ayrıca Devvânî'nin sadece isbât-1 vâcibe ilişkin eserlerinde değil, diğer teliflerinde de Allah'in varlığının ve birliğinin isbatına yer vermesi bu konuya özel bir önem atfettiğini göstermektedir. Dolayısıyla bu çalışmada cevabını aradığımız en temel soru şudur: Devvânî, ileri yaşlarında müstakil olarak yazdığı ikinci isbât-1 vâcib risalesini niçin yazma gereği duymuştur? Elbette bu sorunun cevabını bulabilmek için öncelikle iki risale arasında muhteva bakımından nasıl bir fark olduğunun ortaya konul-

1 İslâm düșüncesinde İsbât-1 vâcib hakkında yazılan literatür ile ilgili geniș bilgi için bk. Bekir Topaloğlu, İslâm Kelâmcıları ve Filozoflarına Göre Allah'ın Varlığı (İsbât-ı Vâcib), Ankara: Diyanet İşleri Başkanlığı Yayınları, (tsz), s. $113 \mathrm{vd}$.

2 Celâleddîn ed-Devvânî, Risâletü İsbâti'l-vâcibi'l-cedîde, Seb'u Resâil içinde, nşr. Ahmed Tuysirkani, Tahran: Merkez-i Neşr-i Miras-1 Mektub, 2002, s. 117-170 ; a. mlf., Risâletü İsbâti'l-vâcibi'l-kadîme, Seb'u Resâil içinde, nşr. Ahmed Tuysirkani, Tahran: Merkez-i Neşr-i Miras-1 Mektub, 2002, s. 69113. 
mas1 gerekir. İkinci olarak da Devvânî'nin ikinci risalesinde hem isbât-1 vâcib hem de mârifetullah konusunda önceki tartışmalara nasıl bir katkısının olduğunun belirlenmesi hedeflenmektedir. Ancak Devvânî'nin mezkûr tartışmalara katkısının ne olduğunun belirlenebilmesi için ondan önceki tartışmaların ana hatlarının tespiti önem arzetmektedir. Dolayısıyla temelde iki bölüme ayırdığımız ve ilk kısımda Devvânî öncesi İslâm düşüncesinde isbât-1 vâcib ve mârifetullah hakkındaki düşüncelerin; ikinci kısımda da Devvânî'nin konuya ilişkin fikirlerinin tartışılacağı bu çalışmada, cevabını aradığımız soruları genel olarak şu şekilde zikredebiliriz:

Allah'ın varlığına inanan bir kişi niçin O'nun varlığının ispatlamak üzere delillere ihtiyaç duyar?

İslâm düşüncesinde isbât-1 vâcib risalelerinin yazılmasına niçin ihtiyaç duyulmuştur?

İslâm düşüncesinde yazılan isbât-1 vâcib risalelerinin muhtevası nedir?

Hem İslâm düşüncesinde hem de Osmanlı düşünce geleneğinde Devvânî'nin görüşleri nerede durmaktadır?

\section{1. İslâm Düşüncesinde İsbât-1 Vâcib Problemi}

İslâm düşüncesinin temel tartışmalarından biri olan varlık (vücûd) problemi bağlamında ele alınan isbât-1 vacib meselesi çeşitli şekillerde tartışılmaktadır. Tartışmanın merkezinde ise çalışmanın da temel sorularından biri olan şu soru yer almaktadır: Tanrı inancına sahip bir kimse, O'nun varlığını kanıtlamaya niçin ihtiyaç duyar? Ya da bir başka şekilde soruyu soracak olursak, Tanrı inanc1nın iknâi olmasının yanı sıra akla dayalı olabilmesi için insanın delile ihtiyacı var mıdır? Bu sorular doğru bir şekilde cevaplandırılırsa İslâm düşüncesinde hem müstakil olarak hem de metafizik düşünceye dair yazılan eserlerde özel bir bölüm ayrılan isbât-1 vacib konusu ile ilgili literatürün yazılma nedeni açıklığa kavuşacaktır.

Düşünce tarihi boyunca Allah'ın varlığına dair birçok delil ileri sürülmüştür. Ancak bunları kategorize etmek gerekirse kozmolojik, teleolojik ve ontolojik delil şeklinde yapmak mümkündür. İslâm düşüncesinde ise kelamcıların hudûs delili ve filozofların imkân 
delili ön plana çıkmaktadır. ${ }^{3}$ Ancak biz burada genel itibariyle mezkûr delillerin üzerinde durmaktan ziyade İslâm düşüncesinde Allah'ın varlığının isbatı problemine ilişkin eserlerin yazılma sebebini ortaya koymayı hedeflemekteyiz. İslâm entelektüel geleneğinde isbât-1 vâcip risalelerinin müstakil olarak yazılması XIII. yüzyıldan itibaren olduğu görülmektedir. Bu dönemden önce ise mezkûr problem, müstakil olarak ele alınan eserlerden daha çok nazar bahislerinde ve metafizik ilminin meseleleri içinde Vâcibü'1-Vücûd ve sıfatları, Allah-âlem ilişkisi gibi konular ile birlikte incelenmektedir. XIII. yüzyıldan sonra ise isbat-1 vâcib problemi ile ilgili müstakil risaleler yazılmış ve bu eserlerde Allah'ın varlığı ve birliğinin ispatı ile birlikte sıfatları da incelenmiştir. ${ }^{4} \mathrm{Bu}$ modelde yazılan bir eser ise çalışmamızın temel kaynağ1 olan Devvânî'nin Risâletü İsbâti'l-vâcibi'lcedîde'sidir. On dört fasıldan meydana gelen eserinde Devvânî, ilk fasılda Vâcibül-Vücûd'un varlığının ispatına yer verir. Daha sonra ise her bir fasılda sırasıyla Allah'in zâtı, birliği ve sıfatlarını ele almakta, eserin son fasıllarında da Allah-âlem ilişkisi ile ilgili olarak, âlemin mükemmelliğini vurguladığı Allah'in hikmeti ve cömertliği konularını incelemektedir. ${ }^{5}$

3 Recep Alpyağıl, Gelen-eksel ve Çağdaş Metinlerle Din Felsefesine Dair Okumalar, I, İstanbul: İz Yayınc1lik, 2011, s. 249 vd.

4 Bekir Topaloğlu, a.g.e., s. 108-110.

5 Devvânî'nin ismi mezkûr eseri, teknik bakımdan Șiî bir fakih olan Sadreddîn Muhammed b. İbrahim b. Muhammed eş-Şîrâzî'nin (ö. 903/1498) fí İsbâti'lBârî Teâlâ ve Sifatihi'l-Husnâ (S.K. Corlulu Ali Paşa Böl. no: 304, vr. 126_

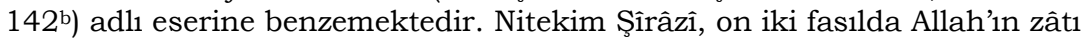
ve sıfatlarını ele alırken; Devvânî, on dört fasıldan oluşan eserinin ilk faslında Allah'ın (Vâcibü'l-Vücûd) isbatını, daha sonra da sırasıyla Allah'ın zât1, birliği ve sıfatlarını incelemektedir. O, Allah'ın sıfatlarını (ilim, kudret, irade, hayat, işitme, görme ve kelam) her bir fasılda ayrı ayrı incelerken, eserin son fasıllarında da kaza ve kader, Allah'ın hikmeti ve cömertliği konularına yer vermektedir; eş-Şîrâzî’nin bu eserine oğlu Mîr Giyâseddîn Mansûr b. Muhammed eş-Şîrâzî (ö. 948/1542) Keşfü'l-Hakâ'iki'l-Muhammediyye adiyla şerh yazmıştır. Babası gibi meşhur kitaplara şerh yazmakla birlikte kelâm, mantık, İşrâk felsefesi, İbn Sînâ felsefesi, astronomi ve matematik gibi alanlarda da eser telif eden Mîr Giyâseddîn asıl ününü babası Mîr Sadreddîn eşŞîrâzî ile Devvânî arasındaki ilmî tartışmalarda babasının yanında yer alarak Devvânî'nin birçok eserine reddiye yazması ile kazanmıştır. Bk. Harun Anay, "Mîr Giyâseddin Mansûr" DİA, XXX, s. 125-128; Devvânî'nin Risâletü 
Risâletü İsbâti'l-vâcibi'l-cedîde adlı eserinde isbât-1 vâcibe ve mârifetullah'a ilişkin görüşlerini ikmal eden Devvânî, eserin başında kendinden önceki delillerin genel bir analizini yapmakta ve hem filozofların imkân deliline hem de kelam bilginlerinin hudûs deliline atıf yaparak Allah'ın varlığını ve birliğini ispatlamaya çalışmaktadır. Müstakil risalelerinin yanı sıra bütün eserlerinde Allah'ın varlığını açıklama gayreti içinde olan Devvânî'ye göre Allah'ın varlığının isbat1 ile ilgili açıklama felsefenin en önemli problemlerinden biridir. ${ }^{6}$ Devvânî'nin görüşlerine geçmeden önce onun da temel referans noktaları olan imkân ve hudûs delillerine ve dolayısıyla mârifetullah konusunda yapılan tartışmaların genel olarak analiz edilmesi konunun daha iyi anlaşılmasına imkân verecektir. İslâm düşünürlerinin İsbât-1 vâcib ile ilgili tartışmalarının merkezinde tek bir amaç ortaya çıkmaktadır ki, bu da mârifetullah'tır. Problemi soru formunda şu şekilde ifade edebiliriz; Allah'in hakikatini bilmek mümkün müdür? Konuyla ilgili Meşşâî felsefede mârifetullah'n imkânı meselesi ön plana çıkarken, kelâm bilginlerinde ise problem iki aşamada tartışılmaktadır: Birinci aşama, mârifetullah zorunlu olarak mı yoksa kesbî bilgi ile mi olduğu meselesidir. İkinci aşama ise, mârifetullah hakkında yapılan nazar/istidlâl, nakil ile mi yoksa akıl ile mi vâciptir.

(I) İsbât-1 vâcip konusunda birinci tartışma, Mârifetullah'in imkânı: İsbât-1 vâcib problemini filozofların düşüncesine göre şu sorular çerçevesinde ele alabiliriz; İnsanın Allah'ı bilmesi mümkün müdür? Şayet mümkünse bu bilgi hangi vasıtasıyla gerçekleşir? Bu bilgi çeșidinin sınırı ve imkânı nedir?

İsbâti'l-vâcibi'l-kadîme adlı eserine kendisinden sonraki dönemlerde birçok şerh yazılırken (bk. Bekir Topaloğlu, a.g.e., s. 116), Risâletü İsbâti'l-vâcibi'tcedîde adlı eseri üzerine tespit edebildiğimiz kadarıla iki tane şerh yazılmıştır. Bunlardan biri, Abdülkâdir b. Muhyiddin b. Mustafa el-Cezâirîye (ö.1300/1883) ait (S.K. Fatih Böl., no: 3031, vr.1-90); diğeri de müellifi tespit edilememiş olan Şerh İsbâti Vâcibi'l-Vücûdi'l-cedîd li'd-Devvânî adlı eserdir. (S.K. Fazıl Ahmed Paşa Böl., no: 201, vr. 1-92.)

6 Celâleddîn ed-Devvânî, "Şevâkilü'l-hûr fî Şerhi Heyâkili'n-nûr", Selâsü Resâil içinde, Meşhed: Mecmaü'l-Buhûsi'l-İslâmiyye, 1991, s. 160-161. 
İslâm entelektüel geleneğinde genel olarak felsefesini varlık (vücûd) üzerine inşâ eden İbn Sînâ'nın (ö. 428/1037) isbât-1 vâcib konusunda da önemli katkıları olmuştur. Çünkü onun sisteminde Allah'ın varlığının isbatı, gerçekte varlığın (vücûd) bilgisine elde etmek manasina gelmektedir. Filozof, konuyla ilgili çeşitli deliller ileri süren düşünürlerden farklı olarak işe Allah'ın varlığının hangi ilmin problemi olduğunu tartışmakla başlar. Mutlak olarak felsefeyi (elhikmetü'l-mutlaka) "en üstün bilinen hakkındaki en üstün bilgi", "en doğru, en sağlam bilgi" şeklinde tanımlayan İbn Sînâ, metafiziğin konusunu da "varlık olması bakımından varlık" olarak belirler. Zira filozofun felsefî sisteminde Tanrı'nın varlığının felsefî bir problem olması bir zorunluluktur. İbn Sînâ, el-îlâhiyyât'ta Allah'in varl1ğının metafizik ilminin konusu olmasının mümkün olmadığını, ancak bu ilmin bir problemi olabileceğini söyler. Çünkü Allah’ın varlığının başka bir ilimde problem olarak tartışılması mümkün değildir. Metafizik ilmi dışında hiçbir ilim Allah'ın varlığını ispat edemez. Benzer şekilde hiçbir ilimde Allah'n varlığının herhangi bir şekilde problem olmadığını varsaymak da doğru değildir. Çünkü hiçbir ilimde Allah'in varlığı problem edinilmediği takdirde ya O'nun varlığı kendiliğinden apaçıktır ya da açıklanmasından ümit kesilmiştir. Hâlbuki ne O’nun varlığı kendiliğinden apaçıktır ne de açıklanmasından ümit kesilmiştir. Zira Allah'ın varlığının birtakım delilleri vardır. Ayrıca açıklanmasından ümit kesilen bir şeyin var olduğunu nasıl söyleyebiliriz? Dolayısıyla İbn Sînâ'ya göre var olan (mevcûd) olarak Tanrı metafiziğin bir meselesidir. ${ }^{7}$ Hatta filozof, el-îlâhiyyât'ta metafizik ilminin gayesinin, et-Ta'lîkât adlı eserinde de felsefenin konusunun "Allah'ı bilmek"8 (el-ma'rifetü billâhi te'âla) olduğunu ifade etmektedir. el-îlâhiyyât adlı eserinde şey (eş-şey') ve zorunlu (ez-zarûrî) kavramları gibi, var olan (el-mevcûd) kavramının insan nefsinde apriori (bedihî) olarak tasavvur edildiğini söyleyen İbn Sînâ, var olan (mevcûd) kavramının bedihî oluşundan hareketle bir

7 İbn Sînâ, Metafizik, I, nşr. ve trc. Ekrem Demirli-Ömer Türker, İstanbul: Litera Yayınc1lik, 2004, s. 3-4.

8 İbn Sînâ, Metafizik, I, s. 20; a. mlf., et-Ta'lîkât, nşr. Abdurrahman Bedevî, Kum: Mektebetü'1-İ'lami'1-İslâmî, (ts.), s. 20-21. 
şeyin var olduğu hususunun açık olduğunu belirtmektedir. Çünkü filozofa göre mezkûr kavramlar en genel, en iyi bilinen olduğundan ve bu niteliği sebebiyle de başka herhangi bir kavramla tanımlanmaya ihtiyaç duymayacak derecede en temeldir. ${ }^{9}$ Ayrıca mevcûd olması bakımından varlık, var olan her şey için ortak bir anlamdır ve kendi olmaklığ bakımından da mahiyeti öğrenilmeye ve ispata muhtaç değildir. ${ }^{10}$ "Varlık vardır." şeklinde ifade edebileceğimiz bir önermeden hareketle varlığın var olmasından hiçbir şekilde şüphe etmeyen ve Zorunlu Varlık olan Tanrı'nın ilk sıfatını "O'nun var ve mevcût olması"11 şeklinde dile getiren İbn Sînâ, felsefenin konusunu mümkün olan en öz şekilde hususileştirerek veya en temel konusunu ön plana çıkartarak felsefeyi, Zorunlu Varlık'ı veya gerçek varlığı bilmek olarak belirtmektedir.

Felsefeyi “Allah'ı bilmek" şeklinde formül eden İslâm filozofları, Allah'ın varlığının bilinmesinin mümkün olup olmadığı hususunda birtakım düşünceler ortaya koymuşlardır. Bu bağlamda "bilinenlerden bilinmeyenlere ulaşma" şeklinde tarif edilen aklî istidlalin ${ }^{12}$ Allah'ın varlığının isbatı için uygulandığında Allah'ın varlığını bilmenin mümkün olup olmadığı tartışmalıdır. Ya da problemi bir başka şekilde ifade edersek, insanın Allah'ın hakikatini tam manastyla bilmesi mümkün müdür. Konuyla ilgili olarak Meşşâî felsefede Fârâbî (ö. 339/950), insanın mârifetullah ile ilgili bilgisinin önsel (evvelî) olmasına rağmen tam manasıyla Allah'ın hakikatini bileme-

9 İbn Sînâ, Metafizik, I, s. 27; İbn Sînâ, en-Necât adlı eserinde de varlığın var olduğunda herhangi bir şüphe olmadığını vurgulamaktadır. İbn Sînâ, Kitâbü'n-Necât, nşr. Mâcid Fahrî, Beyrut: Dârü'l-Âfâki'l-Cedide, 1985, s. 271.

10 İbn Sînâ, Metafizik, I, s. 11.

11 İbn Sînâ'ya göre, Allah'ın diğer sıfatlarının bazısı selb (olumsuzlama), bazısı da izafet niteliği taşır. Fakat bu sıfatların hiçbiri Allah'ın zâtında çokluk ve başkalığa neden olmaz. Bk. İbn Sînâ, Metafizik, II, nşr. ve trc. Ekrem Demirli-Ömer Türker, İstanbul: Litera Yayınc1lık, 2005, s. 113-114.

12 İbn Sînâ, Kitâbu'ş-Şifâ: II. Analitikler, nşr. ve trc. Ömer Türker, İstanbul: Litera Yayınc1lık, 2006, s. 22 vd.; İbn Rüşd, Faslü'l-makâl, nşr. ve trc. Bekir Karlığa, İstanbul: İşaret Yayınları, 1999, s. 65; Seyyid Şerîf el-Cürcânî, Şerhu't-Mevâkıf, I, nşr. Abdurrahman Umeyra, Beyrut: Dârü'1-Cil, 1997, s. 176; Türkçe trc., Ömer Türker, İstanbul: Kırk Gece Yayınları, 2011, s. 181. 
yeceğini dile getirmektedir. $\mathrm{O}$, insanın sadece eşyanın hakikatine delâlet eden lâzımları ve arazları bildiğini ve dolayısıyla insanın gücünün eşyanın hakikatini bilmeye yetmediğini belirtmektedir. Benzer şekilde insanın, Allah'in hakikatini de bilmesi beklenemez. İnsan sadece Allah'in zorunlu varlık olduğunu ve vahdaniyet gibi s1fatlarını bilebilir. ${ }^{13}$ Mezkûr düşünceyi daha sonra Fahreddîn erRâzî’nin (ö. 606/1210) basit lâzımların ve hakikatlerin bilinebileceğini söyleyerek eleştirdiği görülmektedir. Razi, basit lâzım ve basit hakikatlerin bilinebileceğini, ancak basit lâzımların var olduğu eşyanın hakikatinin bilinemeyeceğini söylemektedir. Fakat Meşşâî felsefede bir şeyi bilme onun illetini de bilme manasına geldiğinden dolayı essyanın hakikatinin gerçek anlamda bilinememesi, eşyanın nihai illeti olan Allah'in da hakikatinin bilinemeyeceği anlamına gelmektedir. ${ }^{14}$ Benzer şekilde İbn Sînâ, et-Ta'likât'ta insanın birtakım delillere ulaşmasının eşyanın hakikatine vâkıf olduğu manasına gelmediğini söylemektedir. Esasen İbn Sînâ felsefesinde eşyanın hakikatine tam manasıyla ulaşmak insan kapasitesini aşan bir durumdur. Bu bakımdan da insanın, varlığı zorunlu olanın hakikatini tam anlamıyla bilmesi mümkün gözükmemektedir. Varlığ1 zorunlu olan hakkında bilinen tek şey ise varlığının zorunlu oluşudur. Fakat bu bilgi de O'nun hakikatinin tam manasıla idrak edildiği anlamı taşımamaktadır. ${ }^{15}$ Esasen filozofun varlığ zorunlu olanın kanıtlanması hususunda "delil" kavramını kullanması ve ayrıca Allah hakkında da sebebini ortaya koyma anlamında bir burhândan söz edi-

13 Fârâbî, et-Ta'lîkât, nşr. Cafer Al-i Yasin, Beyrut: Dârü'l-Menâhil, 1988, s. 4041; İbn Sînâ, et-Ta'lîkât, s. 34-35; esasen her ne kadar Fârâbî'nin olduğu düşünülerek et-Ta'lîkât adlı eser, Fârâbî'ye atfen neşredilmiş olsa da mezkûr eserin Fârâbî'nin olmayıp İbn Sînâ'nın eserinin başka bir nüshası olduğu son yıllarda ortaya çıkmış bulunmaktadır. Bu durum her iki metin karşılaştırıldığında rahatlıkla anlașılmaktadır. Ancak Devvânî, Risâletü İsbâti'lvâcibi'l-cedîde adlı eserinin birçok yerinde Fârâbî'nin et-Ta'lîkât'ına atıf yaptığından dolayı burada mezkûr eseri zikretmeyi uygun bulduk.

14 İsmail Hanoğlu, Râzî’nin Düşüncesinde Felsefenin Temel Disiplinleri ve Pozitif Bilimler, Ankara: Araştırma Yayınları, 2014, s. 245-246.

15 İlhan Kutluer, İbn Sînâ Ontolojisinde Zorunlu Varlı, İstanbul: İz Yayıncılık, 2002, s. 72 (dnt.); Müstakim Arıc1, Necmettin el-Katibi ve Metafizik Düşüncesi, (Basılmamış Doktora Tezi), İ.Ü. Sosyal Bilimler Enstitüsü, İstanbul, 2011, s. 185 . 
lemeyeceğini söylemesinin, O'nun kendisini nasıl biliyorsa, insanın da benzer şekilde bileceği manasına gelmediğini vurgulamak amacı taşıdığını söyleyebiliriz. Nitekim filozofun sistemine göre nazarî akıl çerçevesinde bir ispat yapmak mümkündür, fakat yapılan bu ispatta, insan aklının sınırları çerçevesinde ulaşılan sonucun Allah katında da aynı şekilde olduğu manasına geldiği düşünülmemelidir. ${ }^{16}$ Çünkü burada yapılan ispat sonucunda elde edilen nazarî bilgi, insanın gücü dâhilindedir. İnsanın gücü dâhilinde elde ettiği bu bilginin Allah'in hakikatinde de aynı olduğunu düşünmek yanlış olabilir. Dolayısıyla insanın Allah'ın hakikatini bilmesi mümkün görünmemektedir. ${ }^{17}$ Benzer düşünceyi Eş'ârî kelâmında bir dönüm noktası olan Cüveynî (ö. 478/1085) de el-Burhân adlı eserinde dile getirmektedir. O, insanın hâdis bir varlık olmasından hareketle sonlu ve sinırlı bir varlık olduğunu vurgulamakta ve sonlu olan bir varlığın sonsuzu tam olarak idrakinin mümkün olmadığını ifade etmektedir. Dolayısıyla her ne kadar nazarî akıl kuvvesiyle insanın fizik ötesi hakkında birtakım bilgiler elde etmesi mümkün olsa da bütünüyle kuşatıcı bir bilgi elde etmesi imkânsız bir durumdur. ${ }^{18}$ Ancak bu insanın hiçbir şekilde bilgi elde edemeyeceği anlamına da gelmemektedir. Çünkü aklın, metafizik meselelerin çoğunda olumlama ve olumsuzlama arasını kuşatmakta yetersiz kalması, bütünüyle kuşatabileceği meselelerde ulaştığı bilginin kesinliğini de ortadan kaldırmaz. ${ }^{19}$

16 Mustakim Arıc1, a.g.e., s. 185; Fârâbî ve İbn Sînâ'ya ait olan Allah'ın hakikatinin gerçek anlamda bilinemeyeceği düşüncesini müteahhirûn dönemi kelâm âlimlerinden Kâdî Beyzâvî de dile getirmektedir. Bk. Kâdî Beyzâvî, Kelâm Metafiziği (Tavâli'u'l-Envâr), nşr. ve trc. İlyas Çelebi-Mahmut Çınar, İstanbul: Türkiye Yazma Eserler Kurumu Başkanlığı Yayınları, 2014, s. 168169.

17 Cürcânî, Şerhu'l-Mevâkıf, I, s. 136; Türkçe trc., s. 146; a. mlf., Şerhu'lMevâkıf, III, s. 206-207.

18 İmâmü'1-Haremeyn el-Cüveynî, el-Burhân fî usûli'l-fikh, I, nşr. Abdülazîm edDîb, Devha: Câmiatu Katar, 1399/1978, s. 142; Ömer Türker, "Kelâm ve Felsefe Tarihinde Fahreddin er-Râzî", İslâm Düşüncesinin Dönüşüm Çağında Fahreddin er-Râzî içinde, (ed. Ömer Türker-Osman Demir), İstanbul: İSAM Yayınları, 2013, s. 29.

19 Ömer Türker, a.g.m., s. 29. 
Metafizik ilminin en temel gayesini mârifetullah şeklinde ifade eden İbn Sînâ, Zorunlu Varlık'ın varlığının duyulurlarla değil, aksine küllî-aklî öncüllerden hareketle ispatlanabileceğini iddia etmektedir. ${ }^{20}$ Esasen filozofun bu iddiasının arka planında dinin beyan ettiği hakikatleri nazarî manada araştırarak dinin ve vahyin aklen temellendirilebileceği çabasının yer aldığı söylenebilir. Başka bir ifadeyle, dinin iknâî olarak söylediği hakikat, felsefî düşünce geleneğinde akıl gücüyle burhanî yoldan yapılmaktadır. ${ }^{21}$ Nitekim Kur'an-1 Kerîm'de Allah'in varlığına delalet eden ve isbat-1 vâcibe ilişkin ayetlerin delillerin muhatabı olan insanların farklı ruhî yapısından dolayı iknâî olduğu bilinmektedir. ${ }^{22}$

Mârifetullah ile ilgili önemli açıklamalar yapan Gazzâlìnin (ö. 505/1111) de Allah'ın hakikatinin bilinip bilinemeyeceği hususunda filozoflar ile benzer görüşleri paylaştığı görülmektedir. Gazzâlî, elİktisâd fi'l-i'tikâd ${ }^{23}$ adlı eserinde Allah'in akılla bilinebileceğini söylerken, el-Maksadü'l-esnâ'da ${ }^{24}$ ve Mişkâtü'l-envâr'da ${ }^{25}$ ise müşahede yoluyla bilmenin mümkün olabileceğini düşünmektedir. Hatta o, elMaksadü'l-esnâ'da Allah'i bilmek ile ilgili olarak biri kâsır (kusurlu), diğeri mesdûd (kapalı) olmak üzere iki yol zikreder. Kâsır yol, insanın kendisinde bulunanlarla benzeterek O'nun isim ve sıfatlarını bilmesi, mesdûd (kapalı) yol ise insanın ilâhlık vasıflarını bütünüyle elde edinceye kadar beklemesi ve nihayetinde ilâh olması durumudur. Ancak ikinci yol, insan için kapalıdır. Zira ilahlık hakikatine ancak Allah sahiptir. Her ne kadar söz konusu ikinci yolun tahkiki marifetin tek yolu olsa da bu mertebeye Allah'tan başkasının sahip

20 İbn Sînâ, Metafizik, I, s. 19.

21 Ömer Mahir Alper, İslâm Felsefesinde Akıl-Vahiy/Felsefe-Din İlişkisi, İstanbul: Ayışı̆̆1 Kitapevi, 2000, s. 208-212; Mustakim Arıc1, a.g.e., s. 184.

22 Bekir Topaloğlu, a.g.e., s. 23-28; M. Sait Özervarlı, "İsbât-1 Vâcib", DİA, XXII, s. 495-497.

23 Gazzâlî, İtikadda Orta Yol, (el-İktisâd fi'l-'itikâd), nşr. ve trc. Osman Demir, İstanbul: Klasik Yayınları, 2012, s. 21.

24 Gazzâlî, el-Maksadü'l-esnâ fì şerhi Esmâillâhi'l-hüsnâ, thk. Fadlou A. Shehadi, Beyrut 1971, s. 42 vd.

25 Gazzâlî, Mişkâtü'l-envâr ve misfâtü'l-esrar, nşr. Abdülaziz İzzeddin esSeyrevan, Beyrut: Âlemü'l-Kütüp, 1986, s. 137. 
olması imkânsızdır. Mezkûr düşünce ise Allah'ı hakikati üzerine O'ndan başkasının bilmesinin mümkün olmadığı sonucunu ortaya çıkarmaktadır. Bu durum, tıpkı peygamberlik makamını peygamberden başkasının bilmemesi veya anlayamaması gibidir. Nitekim Gazzâlî’ye göre ariflerin Allah'ı tanımları, gerçekte O'nu mutlak anlamda tanımaktan aciz olduklarını bilmeleridir. Çünkü ilâhlık sıfatlarına bütünüyle vâkıf olarak hakiki marifetle Allah'ı bilmek muhal olduğundan dolayı Allah'n gerçek manada bilinemeyeceğini bilmek de hakikati bilmek anlamina gelmektedir. Gazzâlî, marifetin sadece keşf ve burhan şeklinde olması durumunda insan için en yüksek mertebeye ulaşılmış olacağını ifade etmektedir. ${ }^{26}$

Filozofların mârifetullah ya da daha özelde varlık hakkındaki düşünceleri neticesinde Allah'ın varlığını isbat bağlamda imkân delili ortaya çıkmıştır. Filozofların delili olarak anılan imkân delili, mümkün varlıkların varlığını yokluğuna tercih edecek zorunlu bir varl1ğın isbat edilmesini amaçlamaktadır. İmkân delili üzerinde daha sonra duracağımız için tekrara düşmemek için burada bu kadar işaret etmekle iktifa ediyoruz.

(II) İsbât-1 vâcip konusunda ikinci tartışma: Mâritefullah (Allah'ı bilmek) zorunlu (fitrî/müşahede) bir bilgi mi; yoksa kesbî (nazar/istidlâl ile oluşan) bir bilgi midir?

Allah'ın varlığının bilinip bilinemeyeceği konusu, İslâm filozoflarının olduğu kadar kelâm bilginlerinin de zihnini meşgul eden bir problemdir. Filozoflar, Allah'ı bilmenin imkânı üzerinde dururken, kelam bilginleri de Allah'ı bilmenin zorunlu ${ }^{27}$ mu yoksa kesbî bilgi mi olduğu hususunda tartışmışlardır. Bazı İslâm bilginleri insanın fitrî olarak Allah'ı bildiğini söylerken, bazıları da akılla, yani aklî istidlâl (nazar) yöntemiyle Allah'ın bilinebileceğini iddia etmişlerdir. Allah'in fitrî olarak bilindiğini söyleyenlerin başında Ebû Hanîfe (ö.

26 Gazzâlî, el-Maksadü'l-esnâ, s. 51-56; a. mlf., Mişkâtü'l-envâr, s. 138.

27 Zorunlu bilgiler, ilk ilkelerdir. Bu bilgiler üç kısma ayrılmaktadır. Bunlar; vicdâniler (nefslerde var olan bilgi), duyusallar (duyunun katkısı olan bilgiler, sezgiler, müşahede gibi) ve bedîhî bilgilerdir. Bk. Cürcânî, Şerhu'lMevâkıf, I, s. 80; Türkçe trc., s. 90. 
150/767) gelir. ${ }^{28}$ Benzer düşünceyi daha sonra isbât-1 vâcib probleminde bir dönüm noktası olan Şehristânî (ö. 548/1153) dile getirmiştir. O, Allah'ı bilmenin fitrî olduğunu ifade ederek, O'nun herhangi bir şeyle delil getirilemeyecek kadar iyi bilinen olduğunu belirtmektedir. Bu yüzden Allah'ı inkâr eden kişi, gerçekte kendi varlığını inkâr etmiş olur. Çünkü Allah'ı inkâr eden bir nevi, O'nu doğrulamış olmaktadır. Bu ise başka bir şekilde Allah'ın varlığını ispattır. ${ }^{29}$ Mârifetullah'in fitrî olduğu düşüncesini İbn Arabî'nin (ö. 638/1240) Fahreddîn er-Râzî̀ye yazmış olduğu mektubunda da dile getirdiği görülmektedir. İbn Arabî̀ye göre, "Allah'ı bilmek, O’nun varlığını bilmekten başkadır.” Burada İbn Arabî, aklın Allah'ı ancak var olması ve O'nun ne olmadığı (selb) yoluyla bilebileceğini ifade etmektedir. Hâlbuki Allah, aklın O'nu nazar ve tefekkür ile bilmesinden daha yücedir. Bu durumda Allah ancak müşahede yoluyla bilinebilir. ${ }^{30}$

Mârifetullah'ın kesbî olduğunu ise Mu'tezile, Ebu'l-Hasen elEş’ârî (ö. 324/935-6) ve onun ekolünden bazı bilgilerin dile getirdiği görülmektedir. Nitekim Kâdî Abdülcebbâr'a (ö. 415/1025) göre Allah'ı bilmek zorunlu olsaydı, gecenin karanlık, gündüzün aydınlık olduğu gibi, insanların farklı düşünmemeleri ve O'nun hakkında hiç kimsenin şüphe veya inkâr etmemesi ve dolayısıyla zorunlu olarak O'nu tanımaları gerekirdi. Hâlbuki Allah'ı bilme noktasında insanlar farklılaşmakta, kimisi varlığını kabul ederken kimisi de inkâr et-

28 Beyazîzade Ahmed Efendi, İmam-ı A'zam Ebû Hanîfe'nin İtikadî Görüşleri (el-Usûlü'l-münîfe li'l-imam Ebû Hanîfe), trc. İlyas Çelebi, İstanbul: İFAV Yayınlar1, 2000, s. 89-90.

29 Şehristânî, Kitâbu'l-Musâraa (Filozoflarla Mücadele), nşr. ve trc. Aygün Akyol-Aytekin Özel, İstanbul: Litera Yayınc1lik, 2010, s. 39.

30 İbn Arabî'nin Fahreddîn er-Râzî̀ye gönderdiği mektup neşredilmiş ve Türkçe'ye tercümesi yapılmıştır. Bk. "Ebu Abdullah Muhyiddin Muhammed b. Ali İ̉nnü'l-Arabi, "Risâle İle'l-İmam er-Râzî", Resâilü İbn Arabi içinde, Lübnan: Dârü'l-Kütübi'l-İlmiyye, 2001, s 184-187"den Türkçe'ye tercüme eden Nesim Doru, “İbn-i Arabi'nin Fahreddin Razi'ye Gönderdiği Mektup”, Dicle Üniversitesi Ilahiyat Fakültesi Dergisi, C. IV, Say1 1, Y11 2002, s. 102. 
mektedir. ${ }^{31}$ Eş'ârî̀ye göre ise Allah'ı bilmek yani mârifetullah ancak, nazar ile meydana gelen kesbî bir bilgidir. Eğer Allah'i bilmek kesbî değil de zorunlu olsaydı, insanların aklına O'nun varlığı ile ilgili birtakım şüphe gelmez ve delile de ihtiyaç duymazlardı. Fakat bazı insanların zihnine Allah'ın varlığı hakkında şüphe gelmekte ve kanitlama ihtiyacı hissetmektedirler. Buradan hareketle de mârifetullah'in zorunlu değil, kesbî olduğunu söylemek mümkündür. Ayrıca insanın kendi varlığı hakkındaki bilgisi zorunludur. Çünkü insanın kendi varlığı hakkında kuşku duyması veya bununla ilgili birtakım yönlendirmeleri dikkate alması uygun değildir. Bununla birlikte insan Allah'a iman ettikten sonra tekrar küfre dönebilir. İnsanın imandan sonra mârifetullah'1 terketmesi imkân halinde olduğuna göre, Allah’ı bilmek zorunlu değil kesbî olmalıdır. ${ }^{32}$ Eş'ârî, tıpkı Descartes'in (ö. 1650) "düşünüyorum o halde varım"33 ifadesinde olduğu gibi, insanın kendi varlığı hakkında şüphe duymaması gerektiğini vurgulamaktadır. Çünkü ona göre insan kendi varlığını zorunlu olarak bilir. Esasen onun burada işaret etmek istediği şey, kendi varlığından kuşku duyan kimsenin Allah'ın varlığını kabul etmesinin bir anlamı olmayacağı düşüncesidir. Bu bakımdan da insan önce kendi varlığından şüphe duymamalı ki onunla mârifetullah hakkında birtakım tartışmalar yapılabilsin. ${ }^{34}$ Mârifetullah ile ilgili bilginin kesbî olduğunu söyleyen Eş'ârînin üzerinde durduğu diğer husus da mükellef kimsenin ilk sorumluluğunun mârifetullah olduğudur. ${ }^{35}$ Zira mârifetullah vâciptir ve zorunlu olsayd1, insanlar

31 Kâdî Abdülcebbâr, Mu'tezile'nin Beş İlkesi (Şerhu'l-Usûli'l-hamse), I, nşr. ve trc. İlyas Çelebi, İstanbul: Türkiye Yazma Eserler Kurumu başkanlığı Yayınlar1, 2013, s. 74, 80, 88, 114.

32 İbn Fûrek, Mücerred Makâlati'ş-Şeyh Ebi'l-Hasan el-Eş'ârî, nşr. Daniel Gimaret, Beyrut: Dârü'l-Maşrık, 1986, s. 248, 292.

33 Descartes, Metod Üzerine Konuşmalar, trc. Mehmet Karasan, Ankara: Milli Eğitim Bakanlığı Yayınları, 1997, s. 35.

34 Hüseyin Aydın, Ebu'l-Hasen el-Eş'ârî'de Nazar ve İstidlâl, Ankara, Fecr Yayınlar1, 2012, s. 162.

35 İbn Fûrek, Mücerred Makâlat, s. 250; Bâkillânî, el-İnsâf, nşr. İmadüddin Ahmed Haydar, Beyrut: Âlemü'l-Kütüb, 1986, s. 22; Cürcânî, Şerhu'lMevâkıf, I, s. 165; Türkçe trc., s. 174. 
buna güç yetiremeyebilirdi. Bu yüzden kesbîdir ve vâciptir. Dolay1sıyla mârifetullah nazara dayalı olduğundan kul, ilgili hükmün sabit olması için nazarıyla elde eder ve mükellef olur. ${ }^{36}$

Görüldüğü üzere Allah'ın aklî istidlal yöntemiyle bilinebileceğini iddia edenlere göre Allah'ı bilmek olarak ifade edilen nazar/istidlal zorunludur. Ancak ondan daha öncelikli olan ise aklî istidlali kastetmenin zorunluluğudur. Çünkü aklî istidlâle yönelmek, mutlak olarak vâcip olan aklî istidlalden öncedir. Dolayısıyla o da zorunludur. ${ }^{37}$ İslâm düşünürlerinin bu şekilde Allah'ı bilmenin zorunluluğundan söz etmeleri, hatta bu bilmeyi de aklî istidlal (nazar) ile yapmayı zorunlu görmelerinin arkasında, dinin ortaya koyduğu hakikatleri nazarî olarak incelemenin ötesinde, onların Allah inancına aklî bir açıklama getirme gayreti olduğu düşünülebilir. Zira İslâm düşünürlerinin Allah'ın varlığını ispata yönelik deliller ileri sürmelerinde temel gayenin nazarî olarak bir metafizikten ve mârifetullahtan söz etmek olduğu görülmektedir. Böylece kelâm bilginleri tarafından tartış1an mârifetullah konusunda ikinci bir problem ortaya çıkmaktadır. Mârifetullah hakkında yapılan nazar/istidlâl nazarî olarak mı, şerî̀ olarak mı vâciptir?

(III) İsbât-1 vâcip konusunda üçüncü tartışma: Mârifetullah'in kesbî olduğunu düşünenlere göre nazar/istidlâl nazarî olarak m1; yoksa şer’̂̀ olarak mı vâciptir?

Kur'an-1 Kerîm'de ortaya konan deliller, vahyi kabul etmeyerek tanrı fikrini anlamsız bulan kimselere cevap niteliğinde olmakla birlikte, Allah inancına sahip olan insanlara da Allah'ın varlığ

36 Cürcânî, Şerhu'l-Mevâkıf, I, s. 77; Türkçe trc., s. 88.

37 Cürcânî, Şerhu'l-Mevâkıf, I, s. 165-166; Türkçe trc., s. 174-175; Kâdî Abdülcebbâr, Şerhu'l-usûli't-hamse, s. 114; İmâmü'1-Haremeyn el-Cüveynî, Kitâbü'l-İrşâd ilâ kavâtii'l-edille fì usûli'l-i'tikad, nşr. Esad Temim, Beyrut: Müessesetü'1-Kütübi's-Sekafiye, 1985, s. 29; Türkçe trc., İnanç Esaslarl Kllavuzu, trc. Adnan Bülent Baloğlu vd., Ankara: Türkiye Diyanet Vakfı Yayınları, 2010, s. 29; İbn Fûrek, Mücerred Makâlat, s. 32-33; hem Kâdî Abdülcebbâr hem de Eş'ârî'ye göre kişinin öncelikle yapması gereken şey, Allah'ın bilgisini elde etmektir (mârifetullah). Çünkü Allah'ı bilmek bütün dinî bilgilerin ve inançların aslıdır. Bu yüzden dinî vâciplerden her bir vâcip onun üzerine kuruludur. Bk. Kâdî Abdülcebbâr, a.g.e., s. 114-116; Cürcânî, Şerhu'lMevâkıf, I, s. 165-166; Türkçe trc., s. 174. 
inancının rasyonel bir zeminde gerçekleşmesine imkân tanımaktadır. Nitekim Kur'an-1 Kerîm'de Allah'in varlığına delalet eden ayetlerde nazara (istidlâl) işaret edilerek, bu durumun vücûb olarak algılanması da problemin önemini gözler önüne sermektedir. Meşşâî ekole mensup bir filozof olan İbn Rüşd'ün (ö. 595/1198) Faslü'lmakâl'de işaret ettiği gibi ${ }^{38}$ kelâm bilginleri mârifetullah ile ilgili nazarın vücûbiyeti konusunda birtakım fikirler ileri sürmüşlerdir. Onlar, mârifetullah ve O'nun hakkında yapilan nazarın vâcip olduğu noktasında ittifak ederken, mârifetullah ile ilgili yapılan nazarın nakil ile mi yoksa aklî olarak mi vâcip olduğu hususunda ihtilaf etmişlerdir. İbn Fûrek'in (ö. 406/1015) Eş'ârî'den naklettiği gibi, mükellef kimsenin ilk sorumluluğu mârifetullah'tır. Başka bir ifadeyle mârifetullah'a götürecek nazar ve istidlâlde bulunmaktır. Ona göre mârifetullah'a ancak nazar ve istidlâl yoluyla ulaşılabilir. 39 Mârifetullah'a ancak nazarla ulaşabileceği konusunda ittifak eden Eş'ârî ve Mu'tezile'nin ihtilaf ettikleri nokta ise ilgili nazarın nakil ile mi, yoksa akıl ile vâcip olduğudur. Eş'ârî, konuyla ilgili olarak biri, nazarın vücûbiyetine delalet eden ayet ve hadislerden istidlâl, ${ }^{40}$ diğeri de mârifetullah'ın bütün Müslümanların ittifakıyla vâcip olması şeklinde iki delil ileri sürmüştür. Eş'ârî̀nin delil olarak sunduğu ayetlerden anlaşıldığı üzere, Allah, Yaratıcı ve sıfatları hakkındaki nazarı emretmiştir. ${ }^{41}$ Fakat Seyyid Şerif el-Cürcânî, (ö. 816/1413) Eş'ârî̀nin ileri sürdüğü bu delillerden her ikisinin de zannî olduğunu düşünmektedir. Zira emir kipi bazen vâciplikten başka bir anlama da delalet edebilir. Ancak mârifetullah nazarla tamamlanır ve

38 İbn Rüşd, Faslü'l-makal, s. 64-67.

39 İbn Fûrek, Mücerred Makâlat, s. 250; Bâkillânî, el-ínsâf, s. 25; Kâdî Abdülcebbâr, Şerhu'l-usûli'l-hamse, s. 110, 144; Teftâzânî de İslâm düşünürlerinin mârifetullah hakkında nazarın vâcip olduğu konusunda ittifak ettiklerini, ancak söz konusu nazarın şer'an mı yoksa akıl ile mi vâcip olduğunda ise ihtilaf ettiklerini belirtmektedir. Teftâzânî, Şerhu'l-Makâsıd, I, nşr. Abdurrahman Umeyra, Beyrut: Âlemül-Kütüp, 1998, s. 262.

40 Mesela, "De ki: Göklerde ve yerde neler var, bir baksanıza ..." Yunus, 10/101; "Allah'ın rahmetinin eserlerine bak! Yeryüzünü ölümünden sonra nasil diriltiyor. ...” Rum, 30/50.

41 Cürcânî, Şerhu'l-Mevâkıf, I, s. 147-148; Türkçe trc., s. 157-158; İbn Fûrek, Mücerred Makâlati, s. 31-32; Kâdî Beyzâvî, a.g.e., s. 46-47. 
mutlak vâcibin vâcip olması gibi, kendisiyle tamamlandığı şey de vâciptir. ${ }^{42}$ Eş'ârî'nin mârifetullah konusunda nakli esas almasında temel dayanağı, aklî olarak vâcip olması durumunda peygamber gönderilmeden önce de söz konusu vâcibin gerçekleşmesi gerektiği düşüncesidir. Çünkü böyle bir durumda akıl sahibi kimseler vâcibi terk etmiş olduklarından dolayı peygamber gönderilmeden de azaba uğramaları mümkün hale gelebilir. Bu ise mârifetullah'a dair zorunluluğun ancak şerîatle olduğunu göstermektedir. ${ }^{43}$ Mu'tezile ise mârifetin vâcip olması konusunda akıl'ı esas alır. Hatta Kâdî Abdülcebbâr, nazarı vâciplerin ilki olarak ifade etmektedir. Zira ona göre mârifet, nazara muhtaçtır ve eğer insanın nazar yapması engellenirse onun mükellef tutulması da söz konusu olamaz. ${ }^{44}$ Kâdî Abdü1cebbâr'ın içinde bulunduğu Mu'tezile'ye göre mârifetullah'a ancak aklın delâletiyle ulaşılabilir. Onlara göre eğer mârifetullah hakkındaki nazar akılla değil de şerîatle vâcip olsaydı, peygamberlerin peygamberliklerini ispatlamak üzere gösterdikleri birtakım mucizeler vasıtasıyla meydan okumaları geçersiz kılınırdı. Ayrıca peygamber, Yaratıcı ve sıfatları gibi konularda nazar etmeyi emrettiği zaman kişi, "Nazar vâcip olmadıkça nazar etmiyorum." ve "Şeriat bana göre sübût bulmadıkça da nazar etmem." diyebilir. Bununla birlikte şeriatin sübûtu nazari olduğundan dolayı da nazarın vâcipliği ve şeriatin sübûtu durumlarından her biri, diğerine dayandığından bu imkânsızdır. ${ }^{45}$

Mârifetullah'ın nazar/istidlâl ile olduğunu düşünen kelam bilginleri, isbât-1 vâcip ile ilgili hudûs delilini formüle etmişlerdir. Âlem hâdistir ve varlığının bir başlangıcı vardır. Başka bir ifadeyle âlemin varlığı da yokluğu da mümkündür. Bütün mümkün varlıklar doğ-

42 Cürcânî, Şerhu'l-Mevâkıf, I, s. 148; Türkçe trc., s. 158; Cürcânî, nazarın Eş'ârî'ye göre vâcip olması hususunda bazı sorunlar zikretmektedir. Bk. Cürcânî, Şerhu'l-Mevâkıf, I, s. 148-161; Türkçe trc., s. 158-170.

43 Cürcânî, Şerhu'l-Mevâkıf, I, s. 163; Türkçe trc., s. 172; Kâdî Beyzâvî, a.g.e., s. 46-47.

44 Kâdî Abdülcebbâr, a.g.e., s. 118.

45 Cüveynî, Kitâbü'l-İrşâd, s. 29-30; Türkçe trc., s. 29-30; Cürcânî, Şerhu'lMevâkıf, I, s. 165-166; Türkçe trc., s. 172-173. 
rudan doğruya Allah'a dayanır ve Allah da kâdir-i muhtârdır. Dolayısıla mümkün ve hâdis olan âlem bir müessire muhtaçtır. Allah'tan başka bir müessir ise yoktur. ${ }^{46}$ Hudûs delilini ilk defa Şehristânî'nin filozofların kullandığı imkân delili ile birlikte mezcederek kullandığ1 görülmektedir. İnsanın Allah’ı bilmesinin fitrî olduğunu söyleyen Şehristânî, Nihâyetü'l-ikdâm'da âlemin bir Yaratıcısının olduğunu bilmenin bedihî olduğunu ifade etmektedir. ${ }^{47}$ Daha sonra Fahreddin er-Râzî ise mârifetullah konusunda nazar ve müşahede şeklinde iki yol olduğunu söylemekte ve metafizik bilgide olduğu gibi mârifetullah ile ilgili de kesin bilgiye ulaşmanın imkânsız olduğunu, bu konuda nihaî olarak daha tercih edilebilir olanı almanın yeterli olacağını ifade etmektedir. O, el-Metâlibü'l-âliye ${ }^{48}$ adlı eserinde kendinden önce ileri sürülen farklı delilleri değerlendirir ve ardından kendi tasnifini ortaya koyar. Bu bağlamda Râzî'nin Allah'ın bilgisini sağlayan delilleri öncelikle kesinlik bildiren ve iknâî olarak, ardında da imkân ve hudûs delilleri temelinde zâtların imkânı, s1fatların imkânı, zâtların hudûsu ve sıfatların hudûsu başlıklarında incelediği görülmektedir. ${ }^{49}$

Görüldüğü üzere isbât-1 vâcib problemi, müteahhirûn döneminde farklı bir boyutla tartışılmaktadır. Bu dönemde imkân ve hudûs delilleri birlikte kullanılmakla birlikte, mezkûr delillere birtakım eleştiriler de yöneltilmiştir. Bu dönemde yapılan eleştirilerden biri, belki de en önemlisi devr ve teselsül konusundadır. İllet ve ma'lûl silsilesinin kadîm bir illette veya müstakil fâil illette durması gerektiği düşüncesine dayanan teselsül, ilk dönemden itibaren çeşitli yöntemlerle geliştirilmiştir. Ancak imkân ve hudûs delilleri bağlamında teselsülün reddine yönelik akıl yürütmelerin ele alındığı

46 Bâkillânî, el-İnsâf, s. 44 vd.; Cüveynî, Kitâbü'l-İrşâd, s. 38-39; Türkçe trc., 44-45; Cürcânî, Şerhu'l-Mevâkıf, I, s. 143; Türkçe trc., s. 152-153.

47 Şehristânî, Nihâyetü'l-ikdâm fî ilmi'l-kelâm, nşr. Alfred Guillaume, London: (y.y.), 1934, s. 123-124.

48 Fahreddin er-Râzî, el-Metâlibü'l-âliye mine'l-ilmi'l-ilâhî, I, nşr. A. Hicâzî es-Sekkâ, Beyrut: Dârü'l-Kütübi'l-Arabî,1987, s. 71 vd.

49 Muammer İskenderoğlu, "Fahreddin er-Râzî'de İsbât-1 Vâcib ve Tanr1-Âlem İlişkisi”, İslâm Düşüncesinin Dönüşüm Çağında Fahreddin er-Râzî içinde, (ed. Ömer Türker-Osman Demir), İstanbul: İSAM Yayınları, 2013, s. 474. 
müstakil eserlerin yazılması ise Râzî ve sonrasında gerçekleşmektedir. Nitekim devr ve teselsülün geçersizliğinin burhanî olarak nasıl ispatlanabileceği tartışması Kâtibi ve Nasîreddin Tûsî arasındaki mektuplaşmanın ${ }^{50}$ konusu olurken, Fahreddin er-Râzî, Teftâzânî, Cürcânî ve Devvânî de illetlerin teselsülünün iptali konusunda başlıca üç burhan olduğunu ileri sürmüştür. Bunlar: Burhân-1 tatbîk, burhân-1 müzâyefe ve burhân-1 arşîdir. ${ }^{51}$ Elbette konuyla ilgili en dikkat çeken metinlerden biri Devvânî'nin Risâletü İsbâti'l-vâcibi'lkadîme adlı eseridir. Devvânî'nin mezkûr eserindeki temel referans kaynakları Kâtibî ve Tûsînnin zikredilen tartışma metinleri ve Cürcânî'nin Şerhu'l-Mevâkıf'ıdır. Temel amacı filozofların ve kelâm bilginlerinin isbât-1 vâcib konusunda ortaya koydukları delilleri açıklamak olan Devvânî, Risâletü İsbâti'l-vâcibi'l-kadîme adlı eserinde öncelikle Zorunlu Varlık (Vâcibü'1-Vücûd) olan Allah'ın varlığının ispat1 hakkında birçok delil (burhân) olduğunu belirtmekte ve söz konusu bu delilleri de mezkûr eserinde "maksad" şeklinde isimlendirdiği iki bölümde ele almaktadır. Birinci maksatta dört yöntem başlı̆̆ında devr ve teselsülün çürütülmesine yönelik delilleri, ikinci maksatta da burhân-1 tadbîk, burhân-1 tezâyüf ve burhân-1 arşî'yi incelemektedir. Yöntem olarak Kâtibî, Tûsî ve Cürcânî'nin görüşlerine de yer veren Devvânî, muhtemel şüpheleri ve soruları zikretmekte, karşılaştırmalı ve eleştirel bir üslubla, ilgili kuşkuları gidermeye, soruları cevaplandırmaya çalışarak, kendi düşüncelerini ortaya koymaktadır. İleri yaşlarında yazdığı ve klasik kelam kitapları-

50 Zorunlu Varlık'ın ispatı ve bu bağlamda teselsül konusu hakkında Necmeddin Kâtibi ile Tûsî mektuplaşarak birtakım münazalar gerçekleştirmişlerdir. Bu tartışmalar hakkında bk. Mustakim Arıcı, a.g.e., s. 40; ayrıca Kâtibî ile Tûsî arasında geçen tartışmalarda yer alan teselsül konusu Murat Demirkol tarafından ele alınıp incelenmiştir. Bk. Murat Demirkol, "Kâtibî ve Tûsî̀de Tanrı'nın Varlığını Zincirlemenin İptali Yoluyla İspatlama”, Kelam Araştırmalar, 9:2, (2011), s. 92-130.

51 Devr ve teselsülün geçersizliği ortaya koyan deliller hakkında geniș bilgi için bk. Osman Demir, "Kelâm'da Teselsülü İptali Delilleri ve İsmail Hakkı İzmirli'nin Teselsül Risâlesi”, İslâm Araştırmalan Dergisi, Say1 23, 2010, s. $117-$ 123; Devvânî de devr ve teselsülün ibtaliyle Allah'ın varlığın isbatını Risâletü İsbâti'l-vâcibi'l-kadîme adlı eserinde ele almıştır. Bk. Devvânî, Risâletü İsbâti'l-vâcibi'l-kadîme, 69-113. 
nın ilâhiyat bölümünde yer alan problemlerin hepsini ihtiva eden bir mahiyete sahip olan Risâletü İsbâti'l-vâcibi'l-cedîde adlı eserinde ise neredeyse bütün delilleri serdetmeyi amaçladığı görülmektedir. Çünkü Risâletü İsbâti'l-vâcibi'l-cedîde'de Allah'ın varlığını ve birliğini (vahdaniyetini) ispatlamada hem aklî delili hem de naklî ve müşahedeyi de esas aldığını söylemek mümkündür. Dolayısıyla ismi mezkûr eserine bütün olarak baktığımızda ve ayrıca eserinin başındaki ifadelerinden onun temel amacinın mârifetullah, yani Allah'1 tanımak olduğunu söyleyebiliriz. Bu bağlamda şu şekilde bir soru sorarak onun görüşlerine geçebiliriz: Devvânî, mezkûr eserinde öncekilerden farklı olarak mârifetullah'ı nasıl ele almıştır?

\section{Celâleddîn ed-Devvânî'nin İsbât-1 Vâcib Problemine Yaklaşımı}

Celâleddîn ed-Devvânî, Risâletü İsbâti'l-vâcibi'l-cedîde adlı eserinin başında gençliğinin baharında isbât-1 vâcib konusunda bir risale (Risâletü İsbâti'l-vâcibi'l-kadîme) yazdığını ve orada birtakım eksiklikleri olmakla birlikte kendisinden önce konuyla ilgili ileri sürülen felsefî delilleri ortaya çıkararak yeniden değerlendirdiğini ve bazı delilleri çürütme yoluna gittiğini ifade etmektedir. Mezkûr risalesinde ise konuyu hem daha net ve kapsamlı hem de daha öz halde ortaya koyduğunu belirtmektedir. ${ }^{52}$ Devvânî, Risâletü İsbâti'lvâcibi'l-kadîme'nin başında "Bu risâleyi kelâm ve felsefenin ortaya koyduğu isbât-1 vâcib hakkındaki burhânları açıklamak üzere yazdım." 53 şeklinde risaleyi yazma amacını açıkça söylemektedir. Esasen Devvânî'nin biri ilmî hayatının başında, diğeri de ilmî bakımdan kâmil kabul edilen ileri yaşlarında yazmış olduğu isbât-1 vâcib risa-

52 Celâleddîn ed-Devvânî, Risâletü İsbâti'l-vâcibi'l-cedîde, s. 118.

53 Celâleddîn ed-Devvânî, Risâletü İsbâti'l-vâcibi't-kâdime, s. 69-70; Devvânî'nin bu eseri üzerine Osmanlı bilim dünyasında birçok şerh ve hâşiye yazılmıştır. Eserin üzerine birçok şerh ve hâşiye yazılmasının temel nedeni olarak müellifinin meşhûr bir âlim olmasının yanı sıra İslâm düșüncesinde ilgili konuların bütününü kapsayıcı tarzda isbât-1 vacip adıyla ilk müstakil eser olmas1nın katkısının olduğunu belirtmek gerekir. Bk. Bekir Topaloğlu, a.g.e., s. 119. 
lelerini telif etmesi, İslâm düşünce ekollerinde ortaya çıkan isbât-1 vâcibe ilişkin görüşlerin bir bütün olarak değerlendirme çabası olduğunu söylemek mümkündür. Zira o, Risâletü İsbâti'l-vâcibi'tkadîme'de istidlâl yollarını ve mârifetullah'ın imkânını ortaya koyarken, Risâletü İsbâti'l-vâcibi'l-cedîde'de ise bu düşünceleri ikmal etmiştir.

Devvânî, Risâletü İsbâti'l-vâcibi'l-cedîde'de isbât-1 vâcib problemlerini uzun uzun ele almaz. Eserin ilk faslında imkân ve hudûs delillerini kullanarak öz halinde Allah'n varlığının isbatını yapar. Esere bütüncül olarak bakıldığında Devvânî̀nin İbn Sînâ'da olduğu gibi, varlığın bedîhî oluşundan hareketle varlık-mahiyet ayrımına dayalı bir varlık tasnifi sunduğu ve bu tasnif üzerinden varlığında ve varlığını sürdürmede hiçbir sebebe muhtaç olmayan bir zorunlu varlık olması gerektiği fikrine ulaştığı görülmektedir. Her ne kadar o açıkça ifade etmese de eserinde kullandığı metot göz önüne alınırsa, yukarıda bahsedilen nazar/istidlâl yoluyla mârifetullah'a ulaşmayı hedeflediğini söylemek mümkündür. Bununla birlikte Allah'ın varl1ğını ve birliğini isbatta Kur'an-1 Kerîm'den bazı ayetleri örnek vererek düşüncesinde nakli esas almaktadır. Dolayısıyla Devvânî, Allah'ın varlığını ispatı için hem aklî hem de naklî delilleri kullanmakla birlikte, müşahedeyi de ihmal etmemektedir. Bu bakımdan onun mezkûr eserini konularını göz önünde bulundurarak bölümleyecek olsak üç kısma ayırabiliriz. Buna göre birincisinde, Allah'in varlığının ve birliğinin ispatını; ikincisinde Allah'ın sıfatlarını; üçüncüsünde de âlemin mükemmelliği düşüncesinden hareketle mârifetullah'a ulaşmayı ele almaktadır. Buradan hareketle Devvânî'nin görüşlerini herhangi bir başlik kullanmadan zikredilen tasnifte ele almayı uygun bulduk.

Devvânî, Risâletü İsbâti'l-vâcibi'l-cedîde'de isbât-1 vâcibe ilişkin imkân ve hudûs delillerini birlikte kullanmaktadır. Onun açıkladığı, filozofların delili olarak bilinen imkân delili, ilk defa Fârâbî'nin felsefî sisteminde görülmüş ve daha sonra İbn Sînâ tarafından geliştirilmiştir. İbn Sînâ, imkân delilini sebep/illet/müessir gibi kavramlarla geliştirerek temelinde illiyet prensibi olan bir mahiyete büründürmüştür. Fakat İbn Sînâ, delili formüle ederken bir taraftan illet- 
lerin bir noktada son bulmasını, diğer taraftan da âlemin zorunlu olarak Allah'tan sudûr ettiğini savunmuştur. Esasen filozofun bu düşüncesi, illiyet anlayışının sonuçlarından biri olan fâil illetin malûlüyle birlikte oluşu ilkesinin zorunlu bir neticesidir. İmkân delilinin bu şekilde illiyet prensibine dayandığı düşüncesi, âlemin ezeliliği fikrine yol açtığ gerekçesiyle Gazzâlî gibi düşünürler tarafından tenkit edilmesine yol açmıştır. ${ }^{54}$ İmkân delili ile ilgili olarak her ne kadar İbn Sînâ'nın düşüncelerine birtakım eleştiriler yöneltilse de Gazzâlî sonrası dönemde birçok kelâm bilgininin filozofun fikirlerini kendi düşüncesi içinde sistemli bir hale getirdiği görülmektedir. Özellikle Allah'ın varlığını ispat bağlamında ele aldıkları devir ve teselsülün iptali konusuyla ilgili olarak imkân ve hudûs delillerine yer vermişlerdir. Zira âlemin hâdis veya mümkün olduğu ispat edildikten sonra her hâdisin bir muhdisi ve her mümkünün bir müessiri bulunduğu ortaya çıkmaktadır. Dolayısıyla devir ve teselsülün geçersizliğine dayanan imkân ve hudûs delilleri Gazzâlî sonrası dönemdeki kelâmcılar tarafından mezc edilerek kullanılmıştır. İlk defa Şehristânî'de görülen imkân ve hudûs delillerinin birbirini tamamlar şekilde kullanımı, Fahreddin er-Râzînin de alternatif tasnifleriyle farklı bir boyut kazanmıştır. ${ }^{55}$ Nitekim Risâletü İsbâti'lvâcibi'l-cedîde'de sık sık Fârâbî ve İbn Sînâ'nın eserlerine atıf yapan Devvânî de hem imkân hem de hudûs delilini aralarında herhangi bir fark gözetmeksizin müssterek olarak kullanmaktadır. Hatta Devvânî, kendisinden önceki isbât-1 vâcib yaklaşımlarını değerlendirerek onları iki gruba ayırmakta, bunlardan birinin doğrudan devir ve teselsülün iptaline dayanarak Zorunlu Varlık'ın ispatını yaptığı$\mathrm{n} 1$, diğerinin de önce Allah'ın varlığını ispat edip daha sonra devir ve teselsülün iptali konusunu ele aldıklarını belirtmektedir. ${ }^{56}$ Dolayısıyla Devvânî'ye göre Vâcibü'l-Vücûd'un varlığının ispat1, biri tesel-

54 Mustakim Arıc1, a.g.e., s. 195; İbn Sînâ'nın imkân delili hakkında bk. Engin Erdem, “İbn Sînâ'nın Metafizik Delili”, Ankara Üniversitesi İlahiyat Fakültesi Dergisi, 52:1 (2011), s. 97-119.

55 Fahreddin er-Râzî, el-Metâlibü'l-âliye mine'l-ilmi'l-ilâhî, I, s. 71 vd.; Şehristânî, Nihâyetü'l-ikdâm, s. 5 vd.

56 Celâleddîn ed-Devvânî, Risâletü İsbâti'l-vâcibi'l-kâdime, s. 70. 
sülün iptali olan iki yoldan biriyle mümkündür. Buna göre VâcibülVücûd mevcuttur ve O'nun yokluğu aklî olarak imkânsızdır. Esasen Devvânî'nin Risâletü İsbâti'l-vâcibi'l-kadîme adlı eserinde zikrettiği delil, aklî yokluğu câiz olan mümkünlerin O'ndan sudûr etmesi bakımından Vâcib'e delalet etmesine dayanmaktadır. Bu durumda zâtına göre zorunlu (vâcib) olan Vâcibü'l-Vücûd, yani Allah medlül konumundadır. O'nun varlığını ispatlayan delil ise aklîdir. Bu noktada âlemin varlığı için filozoflar Allah'ın illet, kelâmcılar ise O'nun iradesiyle fâil olduğunu söyler. Devvânî ise onlar arasındaki isimlendirmeyi dikkate almaksızın, hatta delil konusundaki farklılığ dahi görmezden gelerek, hem filozofların hem de kelamcıların söylediklerini göz önünde bulundurarak eserini Allah'ın varlığının ispatı konusuna tahsis eder. Sonuç itibarıyla da hem imkân hem de hudûs delilini birlikte kullanır. ${ }^{57}$ Muhtemeldir ki, Devvânî'nin konuyla ilgili gençliğinde yazdığı risalede genel olarak devir ve teselsülün geçersizliğini ele alması ve ardından ileri yaşlarında ikinci olarak yazdığı risalede de daha öz halinde önce Allah'ın varlığının ispatını inceleyip, ardından sıfatlar konusuna girmesi, bu yaklaşımının bir neticesidir.

Risâletü İsbâti'l-vâcibi'l-kadîme adlı eserinde genel olarak imkân ve hudûs delilleri ve bu deliller bağlamında devr ve teselsülün iptali konusuna geniş yer ayıran Devvânî, Risâletü İsbâti'l-vâcibi'l-cedîde adlı eserinin birinci faslında isbat konusuna İbn Sînâ'nın yaptığ 1 gibi mutlak varlık kavramının analiziyle başlar. $\mathrm{Bu}$ anlamda Devvânî, İbn Sînâ felsefesinde olduğu gibi, öncelikle varlığı modalite açısından zorunlu ve mümkün şeklinde bir ayrıma tâbi tutar. Ona göre var olan (mevcûd), ya zâtına göre zorunlu (vâcip) ya da zâtına göre mümkündür. ${ }^{58}$ Mümkün varlığın var olması ve var olmamas1 (yokluğu) eşit seviyededir. Buna göre birincisi, vâcip li-zâtihîdir, ikincisi de mümkündür. Devvânî, mümkün varlığın (mümkinü’-

57 Muhammed Ekrem Ebû Gûş, "Risâletü İsbâti'l-vâcib li-İmâmi'd-Devvânî", Mecmû' Selâse Resâil içinde, Amman: Dârü'n-Nûr el-Mübîn, 2013, s. 63.

58 İbn Sînâ, Metafizik, I, s. 35; Devvânî, Risâletü İsbâti'l-vâcibi'l-cedîde, s. 118; a. mlf., "Şevâkilü'l-hûr fî Şerhi Heyâkili'n-nûr", s. 160-161. 
vücûd), varlığı önce veya ardı ardına gelen bazı varlıkların yokluğunda olduğu gibi, bedihî olarak açıklanmaya muhtaç olmadığını belirtmektedir. Buna karşıllk vâcip varlık ise açıklanmaya muhtaçtır. Devvânî'nin burada vâcip varlığın açıklamasında hareket noktasının, "Varlık vardır." önermesi olduğunu söyleyebiliriz. Zira Devvânî’ye göre "var olan (mevcûd)" mefhumunu düşündüğümüzde, akıl bize sadece kendi kendisiyle var olan varlığ 1 verir. Başka bir ifadeyle, var olan (mevcûd) anlamı hakkındaki düşünce, başka bir illet olmaksızın kendisiyle gerçekleşmesi mümkün olan varlığı verir. Nitekim bu düşünceyi Devvânî, "Vâcibü'l-Vücûd vardır."59 önermesi ile desteklemektedir. Ona göre mezkûr önermeyi söylediğimizde varlığı zâtının aynı olan ve varlığında hiçbir illete muhtaç olmayan varlığı kastederiz. Şayet mümkün varlığ göz önüne alarak var olanı (mevcûd) ifade edersek, o asla var olan (mevcûd) olarak gerçekleşmez. Çünkü mümkün varlığın diş dünyada gerçekleşmesi yönündeki bu istidlâl, ya bir illet olmaksızın kendi kendine ya da başkası sebebiyle var olması durumundadır. Birinci durum, yani mümkün varlığın illetsiz kendi kendine var olduğu düşüncesi bedihî olarak muhaldir, ikinci durumda ise İlk'in sonsuza kadar teselsülü ya da devri gerekir. Fakat söz konusu teselsül veya devr ise kendisinde mümkün olan herhangi bir şey bulunmadığı halde Bir'in eseriyle birlikte aksini ispatlama olur ki, Devvânî, bu durumun muhal olduğunu söylemektedir. Şu halde mümkün varlık, var olmadıkça zorunlu olmayandır. Mümkün varlığın zorunluluğu ancak yokluğu bütün yönlerden engellendiğinde gerçekleşir. Dolayısıyla Zorunlu Varlık'ın varlığında hiçbir sebebe muhtaç olmayıp, var olan her şeyin var olabilmek için O'na muhtaç olduğunu ortaya koyan bu istidlâl, Devvânî'ye göre devr ve teselsüle ihtiyaç olmaksızın gerçekleşen güzel bir burhandır. ${ }^{60}$ Devvânî'nin Allah'ın varlığının ispatında İbn Sînâ'nın imkân delilini kullanması ve bu kanıtlama biçimini de devr ve teselsüle muhtaç olmadan yapılan en güzel burhan şeklinde de-

59 Devvânî, Risâletü İsbâti'l-vâcibi'l-cedîde, s. 132.

60 Devvânî, Risâletü İsbâti'l-vâcibi'l-cedîde, s. 118-119; Devvânînnin burada zikrettiği bu delil, daha önce Cürcânî'nin filozofların delili olarak bahsettiği ispattır. Krş. Cürcânî, Şerhu'l-Mevâkıf, III, s. 14. 
ğerlendirmesi, devr ve teselsül ile gerçekte Zorunlu Varlık'ın varlığının ispat edilemeyeceği kanaatinde olduğunu göstermektedir. Aynı düşünceyi ondan önce Kâtibî ve Cürcânî'de de görmekteyiz. Hem Kâtibî hem de Cürcânî, Zorunlu'nun varlığının teselsülün yanlışlığ ile ispat edildiğinde illetin, ma'lûle dayanacağını, bunun ise bir sonuca ulaştırmayacağını ve dolayısıyla yanlış bir ispat şekli olduğunu dile getirmişlerdir. ${ }^{61}$ Yine Cürcânî'ye göre âlemin sahip olduğu hudûs veya imkânından hareketle yapılan nazar/istidlâl, Yarat1cı'nın bilgisini vermektedir. Bu şekilde yapılan bir istidlâlde de âlemin varlığı Yaratıcı'nın varlığını gerektirir. Dolayısıyla bu istidlâlde ne kısır döngü ne de teselsül gerekir. ${ }^{62}$

Devvânî, mezkûr burhanın var olmada hiçbir varlığa muhtaç olmayıp bedihî olarak var olanın varlığı ile ilgili olduğunu söylemektedir. Esasen Devvânî'nin burada söylediği şey şudur: "Var olanın varlığında şüphe yoktur." (lâ şekke fî vücûdi mevcûd). ${ }^{63} \mathrm{Bu}$ ise var olanın bilgisinin bedihîliğini, yani apaçıklığını göstermektedir. Devvânînin bu ifadesi İbn Sînâ'nın mevcûd kavramına yüklediği anlamı hatırlatmaktadır. Nitekim filozof, var olan (mevcûd) kavramının insan nefsinde apriori (bedihî) olduğunu belirtmekte ${ }^{64}$ ve açık, seçik, kendinden yeterli bir kavram olması niteliğinden dolayı da anlamını gerçekleştirmek için başka herhangi bir kavrama ihtiyaç duymadığını söylemektedir. Söz konusu kavram ile ilgili birtakım tanımlamalar yapılması mümkündür, fakat yapılan hiçbir ta-

61 Mustakim Arıc1, a.g.e., s. 202; Devvânînin en güzel kanıtlama biçimi şeklinde ifade ettiği İbn Sînâ'nın Allah'ın varlığını kanıtlama biçimi, mümkün ve zorunlu varlık ayrımına dayalı olan bir delildir. Esasında bu yöntem, İbn Sînâ'nın Allah'ın varlığını kanıtlamasında kullandığı iddia edilen hareket ve nedensellik delilini bir şekilde içinde barındıran bir kanıtlama biçimidir. Konuyla ilgili detaylı bilgi için bk. Ömer Mahir Alper, "İbn Sînâ'da Tanrı'nın Kanıtlanması Sorunu: O Gerçekten Kelâmcilardan Etkilendi mi?” İ.Ü. İahiyat Fakültesi Dergisi, Sayı VII, Y11 2003, İstanbul 2003, s. 61-77.

62 Cürcânî, Şerhu'l-Mevâkıf, I, s. 135; Türkçe trc., s. 145.

63 Devvânî, Risâletü İsbâti'l-vâcibi'l-cedîde, s. 119.

64 İbn Sînâ, Metafizik, I, s. 27. 
nım da var olan (mevcûd) kavramından daha belirgin değildir. ${ }^{65}$ Benzer düşünceyi Fahreddîn er-Râzî'de de görmekteyiz. Râzî, insanın kendi varlığı hakkındaki bilmesinin kesbî değil, apriori olduğunu söylemektedir. Basska bir ifadeyle zihninde varlık tasavvuru olmayan bir kimsenin kendi varlığını da tasavvur etmesi mümkün değildir. Zihninde kendi tikel varlığının bilgisine sahip olmak da aynı zamanda tümel varlığın bilgisine sahip olmak manası taşımaktadır. ${ }^{66}$ Var olan (mevcûd) kavramının bedihîliği konusunda İbn Sînâ, Fahreddin er-Râzî ve Cürcânî ile hemfikir olduğu görülen Devvânîye göre var olan (mevcûd) ifadesiyle eğer zâtı vâcip olan kastedilirse herhangi bir sorun olmaz. Çünkü burada var olan ile kastedilen/istenilen esas itibariyle zâtı vâcip olandır. Ancak var olan ifadesiyle mümkün varlik kastedilirse, bu durumda onun da bir vâcibe dayanması zorunluluğu ortaya çıkar. Çünkü mümkün varlığın varlığı zorunlu değildir ve varlığında bir illete muhtaçtır. Bundan dolayı da onun hakkında "O vardır." ifadesi kullanıldığında o asla var olan olarak bulunmaz. ${ }^{67}$

Var olan (mevcûd) kavramının bedihî oluşundan hareketle Vâcibü'l-Vücûd'un varlığının da apaçık olduğunu vurgulayan Devvânî, zikredilen ispatın kelâmcıların metodundan seçildiğini belirtmekte ve ayrıca İbn Sînâ'nın el-İşârât ve't-tenbîhât adlı eserine atıf yaparak kendi fikrinin filozofun düşüncesine uygun olduğunu açıkça ifade etmektedir. ${ }^{68}$ Devvânînnin kelâmcıların metodu ile kastının onların isbât-1 vâcipte savundukları hudûs delili olduğu aşikârdır. Zira kelâmcı düşünürlerin bu delil formunda şehadet âleminden, yani eserden müessire hareketle Allah'ın varlığını ispatlamaya çalıştıkları görülmektedir. Devvânî’nin mezkûr eserinin bütününe baktığımızda

65 Ömer Mahir Alper, Varlık ve İnsan Kemalpaşazâde Bağlamında Bir Tasavvurun Yeniden İnşası, İstanbul: Klasik Yayınları, 2010, s. 21-22.

66 Fahreddin er-Râzî, el-Mebâhisü'l-meşrikıyye, fi 'ilmi'l-ilâhiyyât ve't-tabîiyyât, I, nşr. M.M. el-Bağdâdî, Bayrut: Dârü'l-Kitâbi'l-Arabî, 1990, s. 97-98; Seyyid Şerif el-Cürcânî, Şerhu'l-mevâkıf, I, s. 220; Türkçe trc., s. 226-227; Eşref Altaş, Fahreddin er-Râzînin İbn Sinâ Yorumu ve Eleştirisi, İstanbul: İz Yayınc1lik, 2009, s. 319-320.

67 Devvânî, Risâletü İsbâti'l-vâcibi'l-cedîde, s. 119.

68 Devvânî, Risâletü İsbâti'l-vâcibi'l-cedîde, s. 119. 
bu yöntem dikkat çekmektedir. Yine onun işaret ettiği pasajında İbn Sînâ, Allah'ın varlığı için her ne kadar birtakım deliller ileri sürülmüş olsa da gerçekte O'nun yaratmasının ve fiilinin de varlığı için bir delil olduğunu dile getirmektedir. Burada İbn Sînâ, "varlık olması bakımından varlık" şeklinde sunulan imkân delilinin en üstün ve güvenilir olduğunu vurgulamakta ve bu delilin benzerlerine Kur'an-1 Kerîm'de işaret edildiğini söyleyerek Fussilet suresinin 53. ayetine atıf yapmaktadır. Hatta İbn Sînâ, ayette geçen "Onlara ayetlerimizi afakta ve nefislerinde göstereceğiz." 69 ifadesinin bir grubun (kavm) yaklaşımına işaret olduğunu belirtmektedir. Ayrıca ayetin devamında yer alan, "Rabbinin her şeye şahit olması sana yetmez mi?" ifadesinden hareketle de kendi düşüncesini ortaya koyan İbn Sînâ, Allah'ın varlığının ispatında varlık kavramını esas alan kendi yaklaşımının aynı zamanda doğruların (sıddîkîn) yolu ve en doğru, güvenilir yol olduğunu belirtmektedir. Filozofun buradaki ifadesinden mümkün varlıklardan hareketle varlığı zorunlu olana delil getirmekten ziyade bizzat O'nu merkeze alan bir yaklaşım sergilediği anlaş1maktadır. ${ }^{70}$ Başka bir ifadeyle filozof, ayetin birinci kısmında eserden müessire, yani Allah'ın fiili olan yaratılmışlardan Yarat1c1'ya, ikinci kısminda da müessirden esere, yani Yaratıc1'dan yaratılmışlara ulaşılabileceğine işaret etmektedir. Bu bağlamda İbn Sînâ, Allah'ın fiili olan varlıkları Allah'a şahit tutmak yerine, Allah'ı onların varlığına şahit tutmaktadır. Zira onun düşüncesinde mümkün âlem, Allah'ın niçin var olduğunu açıklayamaz. Buna karş11ık

69 Fussilet 41/53.

70 İbn Sînâ, İşaretler ve Tembihler, s. 133; İbn Sînâ'nın mezkûr ifadelerini yorumlayan Nasîreddin et-Tûsî, Allah'ın varlığının ispatı hakkında üç farklı yaklaşımdan söz eder. Buna göre, bir grub cisimlerin ve arazların sonradan var olmalarından hareketle Allah'ın varlığını ispata çalışan kelamcılar (mütekellimûn), diğer bir grub, hareketin varlığından muharrike ve buradan da ilk hareket ettiriciye ve nihayetinde İlk İlke'nin varlığına ulaşan tabiat bilimciler (tabîiyyûn) ve üçüncü grup da varlığa istidlal yaparak, onun zorunlu ve mümkün oluşunda Zorunlu Varlık fikrine ulaşan metafizikçilerdir (ilâhiyyûn). Burada üçüncüsü, yani metafizikçiler İbn Sînâ'nın sıddîkler dediği gruptur ki, aynı ifadeyi Devvânî'de de görmekteyiz. Nasîreddîn et-Tûsî, Şerhu'l-İşârât ve't-Tenbîhât, III, nşr. Süleyman Dünya, Beyrut: Müessesetü'n-Numan, 1993, s. 54-55; Mustakim Arıc1, a.g.e., s. 186. 
Allah, sonradan varlığa gelenlerin niçinini açıklar. ${ }^{71}$ Böylece Devvânî’nin, "Vâcibül-Vücûd vardır."72 önermesiyle kastettiğinin Sırf Varlık olduğu ortaya çıkmış bulunmaktadır.

Varlığı zorunlu olanın varlığını ispatı noktasında Devvânî'nin İbn Sînâ'da olduğu gibi varlık kavramından hareket ettiği açıkça görülmektedir. Tartışmanın merkezine vâcip-mümkün kavramlarını yerleştiren Devvânî'nin temel hareket noktasının Vâcibü'1-Vücûd'u tanımaya yönelik olduğunu söyleyebiliriz. Hatta İbn Sînâ felsefesinde olduğu gibi, mevcûd kavramının teşkîk (dereceli) yoluyla varlıklara yüklem olduğu kanaati taşıdığını söylemek mümkündür. ${ }^{73}$ Devvânî, mevcûd kavramının varlığı zorunlu olan ile diğer varlıklar arasında farklılaştığını açık bir şekilde ifade etmektedir. ${ }^{74}$ Mevcûd kavramı, mutlak olduğundan hem zâtı bakımından zorunlu olan Allah'ı hem de var olmada başkasına muhtaç olan mümkün varlıkları kapsar. Zorunlu Varlık olan Allah'ın bütün varlıkların İlke'si ${ }^{75}$ olduğunu söyleyen Devvânî'ye göre her şeyin var olmasının illeti olması hasebiyle İlk İlke'ye bazı istidlâller yapılabilir. O, Allah'in varlığının isbâtına yönelik burhân-ı innî (varlık burhanı) ve burhân-ı limmî (illet burhanı) şeklinde iki istidlâl yöntemi ileri sürüldüğünü, ancak Allah, asla ma'lûl olmayıp, her şeyin illeti olduğundan dolayı O'nun varlığı hakkında getirilen her delilin kaçınılmaz olarak innî olduğunu ifade etmektedir. Başka bir ifadeyle O'nun varlığı ile ilgili ileri sürülen her delil, zâtına (inniyeti) dayanmaktadır. Ona göre innî ve limmî şeklinde zikredilen her iki delil arasında gerçekte bir fark yoktur. Mezkûr deliller, varlık mefhumunun farklı durumlarıdır. Esasında bu deliller, her şeyin varlığının sebebi olan Vâcip Teâlâ'nın

71 Ahmed Nuri, İsbât-ı Vâcib, S.K. Yazma Bağışlar böl., no: 3129, vr. 11-12; Engin Erdem, “İbn Sînâ'nın Metafizik Delili”, s. 116.

72 Devvânî, Risâletü İsbâti'l-vâcibi'l-cedîde, s. 132.

73 İbn Sînâ'da varlık kavramının teşkîk yoluyla yüklem olması, tıpkı, "Kar beyazdır.", "Süt beyazdır.", "Kemik beyazdır.”, "Şeker beyazdır.” önermelerindeki beyazlık kavramının farklı derecelerde yüklem olması gibi bir durumdur. Bk. Engin Erdem, "İbn Sînâ'nın Metafizik Delili”, s. 102.

74 Devvânî, Risâletü İsbâti'l-vâcibi'l-cedîde, s. 129.

75 Devvânî, Risâletü İsbâti'l-vâcibi'l-cedîde, s. 130. 
varlığının ispatı ile ilgili değil, diğer bazı vâciplerle ilgilidir. Bu aç1dan da söz konusu istidlâl, diğer varlıkların illeti olması hasebiyle İlk'i de ilgilendirmektedir. ${ }^{76}$

Devvânî, İbn Sînâ'nın, "Vâcibül-Vücûd'un burhân1 yoktur."77 ifadesini zikrederek zâtı bakımından vâcip olan varlığa istidlâl olmadığını söylemektedir. Çünkü ona göre istidlâl, cüzlerden mürekkep varlık için olabilir. Oysa zâtı vâcip varlık, hiçbir şekilde cüzlere bölünebilen bir terkipte oluşmuş değildir. ${ }^{78}$ Mürekkep olmadığından O'nun cinsi ve fasli yoktur ve tanımı da yapılamaz. O, kendi kendine var olan bir varlıktır, ${ }^{79}$ zâtı bakımından vâcip varlık olması dolayısıyla diğer her şey için illettir, diğerleri ise O'nun ma'lûlüdür. Esasen Zorunlu Varlık ile ilgili burhan olmadığı iddiası da O'nun varl1ğının diğer her şey için delil olmasına dayanmaktadır. Bu yüzden İbn Sînâ'nın mezkûr ifadenin hemen devamında söylediği, "O her şeyin burhânıdır." dir. Nitekim Devvânî, filozofun zikredilen ifadesini açıklama gereği hissederek, Vâcibü'l-Vücûd'un vücûbiyyet sınırına kadar kesilmeksizin devam edip orada durmak zorunda olan ve varlık ve yokluğa eşit mesafede bulunarak üstün gelen tarafın tercih edilmesi üzerine var olan mümkün varlıklardan biri olmadığını belirtmektedir. Eğer O'nun için bu şekilde bir imkân durumu olsaydı O'nunla ilgili burhan tamamlanmaz ve vâcibin varlığı gerekmezdi. Mümkün varlık ise varlık (eys) ve yokluğa (leys) eşit mesafede olup, varlı̆̆1 yokluğuna

76 Devvânî, Risâletü İsbâti'l-vâcibi'l-cedîde, s. 120; Devvânî, Allah hakkında getirilen her delilin O'nun zâtına dayandığı gerekçesi ile burhan-ı innî olduğunu söylemesine rağmen, ondan sonra yaşayan ve İbn Sînâ'nın konuyla ilgili görüşleri üzerine bir eser kaleme alan bir Osmanlı düşünürü Ahmed Nuri, filozofun burhan-1 limmî ile Allah'ın varlığını ispatladığını iddia etmektedir. Ahmed Nuri'nin görüssleri hakkında bk. Engin Erdem, "Ahmed Nuri: İbn Sînâ'nın İsbât-1 Vâcib Yöntemi”, Dini Araştırmalar, XIV, Sayı XXXIX, Y11 2011, s. 50-69.

77 İbn Sînâ, Metafizik, II, s. 99.

78 Devvânî, Risâletü İsbâti'l-vâcibi'l-cedîde, s. 120.

79 Devvânî, Risâletü İsbâti'l-vâcibi'l-cedîde, s. 138-139.

80 İbn Sînâ, Metafizik, II, s. 99. 
tercih edilendir. Burada Devvânî, mümkün varlık hakkında iki açıklamaya yer verir:

Bunlardan birincisi; varlığı zâtına göre tercih edilen olduğu zaman onun yokluğunun mümteni olmasıdır. Çünkü iki taraftan birinin üstünlüğü mukabil tarafın tercih edilmesini gerektirir. Devvânî, mümkün varlık için var olmasının tercih edilmesini onun üstünlüğü olarak değerlendirmektedir. Ancak Zorunlu Varlık düşünüldüğünde durum farklıdır. Zorunlu Varlık'ın varlığının yokluğuna üstünlüğü farzedilmesi durumunda bu üstünlüğün sebebe muhtaç olmadığı manasına gelmektedir ve O'nun var olmasında ise zâtındaki bu üstünlük yeterli olmaktadır.

İkinci açıklamaya göre; eğer mümkün varlığın kendisi için illet olduğu düşünülürse, onun varlığının yokluğunu öncelemesinin gerekliliği ortaya çıkar. Eğer kendi zâtı için illet olmazsa, onun imkânı için sebepsiz olarak yokluğunun var olma ihtimali söz konusu olacaktır. Bu ise sebepsiz olarak var olan varlığın yokluğunun ihtimalini gerektirecektir. Devvânî, mümkün varlığın varlığının üstünlüğe dayandığında zatındaki bu üstünlüğün ortadan kalkması halinde onun yokluğunun söz konusu olabileceğini ifade etmektedir. ${ }^{81}$ Devvânî, bu noktada Fârâbî̀ye atıf yaparak bu durumun onun söylediği şekilde gerçekleştiğini ifade etmektedir. Devvânînnin eserinde yer verdiği Fârâbî'nin metni şu şekildedir:

"Şayet zorunlu olmaksızın varlık silsilesi meydana gelirse ve onun ilkesi kendi zâtı ile meydana gelen mümkün olsaydı, ya onun kendisi için şeyin icadı olması gerekirdi ki bu saçmadır, ya da onun kendisi için onun yokluğunun doğruluğu gerekirdi ki bu ise daha saçmadır." 82

81 Devvânî, Risâletü İsbâti'l-vâcibi'l-cedîde, s. 120-121; a. mlf., Risâletü İsbâti'lvâcibi'l-kâdîme, s. 76; benzer ifadeleri Kemalpaşazâde'de görmekteyiz. Kemalpaşazâde şu şekilde ifade etmektedir: "Vâcibü'l-Vücûd bizzât mevcûddur, O'nun varlığı vâciptir ve yokluğu mümtenidir. Mevcûd olmaması mümkün değildir." Kemalpaşazâde, Risâle fí İsbâti'l-vâcib, S.K. Kılıç Ali Paşa Böl., no: $568 / 6$, vr. $114^{\text {b. }}$

82 Devvânî, Risâletü İsbâti'l-vâcibi'l-cedîde, s. 121; Farabî'nin bu düşüncesinin geçtiği pasajlar için bk. Fârâbî, Kitâbu's-Siyâseti'l-medeniyye, nşr. Fevzi Mit- 
Devvânî'nin bu düşüncesinin biri varlığın üstünlüğü, diğeri de nedensellik olmak üzere iki uzantısının olduğu görülmektedir. Onun isbât-1 vâcib problemiyle de yakından ilgili olarak değindiği varlığın üstünlüğü meselesi, ismini zikrederek atıf yaptığı Fârâbî'nin Kitâbu Ârâu ehli'l-medîneti'l-fâzıla adlı eserinde vurguladığı bir problemdir. Fârâbî, Bir olan Vâcibül-Vücûd'un her türlü eksiklikten arınmış, bu özelliği dolayısıyla da varlığının en üstün varlık ve diğer bütün varlıklardan önce gelen olduğunu belirtmektedir. Vâcibü'1Vücûd, varlık üstünlüğü bakımından en yüksek ve kemâl (mükemmellik) bakımindan da en üst mertebededir. Bu yüzden de O'nun varlığına yokluğun karışması mümkün görünmemektedir. Dolayısıyla O'nun zâtında herhangi bir şekilde bilkuvvelik olmadiğından O'nun varlığının mümteni olması da imkânsızdır. ${ }^{83}$ Devvânî de Fârâbî'de olduğu gibi, Vâcip Varlık söz konusu olduğunda O'nun zâtının varlığının yokluğunun mümkün olmadığını ve O'nun sebepsiz olarak var olmasını zâtının üstünlüğünden dolayı olduğunu belirtmektedir. Ancak Devvânî, Vâcibü'1-Vücûd'un diğer varlıklara olan üstünlügünü vurgulamakla birlikte, varlığının ise sadece zâtî üstünlüğüne dayanmadığını ifade etmektedir. Devvânî'ye göre, O'nun var olması yokluğunu imkânsız kılmaktadır. Vâcibü'lVücûd'un kendi zâtı bakımından var olması, hem zâtı itibariyle yokluğunun imkânsızlığını hem de O'nun mükemmelliğini ortaya koymaktadır. ${ }^{84}$ Devvânî'nin bu ifadelerinden sadece üstünlük kavram1na dayanılarak Vâcibü'l-Vücûd'un varlığının ispatı yapılamayacağ1 kanaatinde olduğu anlaşılmaktadır.

İsbat-1 vâcip ile ilgili Devvânî'nin üzerinde durduğu diğer bir husus ise nedensellik problemi bağlamında Allah'ın varlığının sebebinin kendisi olmasıdır. Devvânî’nin "tam illet (illetü’t-tâmme)", "nâkıs

ri Neccâr, Beyrut: Dâru'l-meşrık, 1993, s. 56-57; a. mlf., "Felsefenin Temel Meseleleri (Uyûnü'l-mesâil)", İslâm Filozoflarından Felsefe Metinleri içinde, İstanbul: Klasik Yayınlar1, 2005, s. 118.

83 Fârâbî, Kitâbu Ârâu ehli'l-medîneti'l-fâzıla, s. 37-38; Benzer düşünce İbn Sînâ'da da görülmektedir. Bk. İbn Sînâ, el-Iş̧ârât ve't-Tenbîhât, s. 133.

84 Devvânî, Risâletü İsbâti'l-vâcibi'l-cedîde, s. 122. 
illet"85 ve "fâil illet" kavramlarından hareketle Allah'ın varlığının zâtından başka bir sebebinin olamayacağını açıkladığı görülmektedir. Ona göre bir şeyin kendisi için illet olması câizdir. Zira mümkün ve vâcip bütün varlıklar kendisinden başka bir illeti olmayan Bir'e muhtaç olan mümkün varlıklardır. Bir'in illeti ise ya O'nun cüz'ü ya da O'nun dişında başka bir şey olur. Cüz'ü olması durumunda cüzlerden birinin diğerlerine ihtiyaç duyması gerekir ki, bu saçmadır. O'nun kendisi dişından olması durumunda ise O'nun başka bir varlığı ihtiyacı ortaya çıkacağından bu da saçmadır. Devvânî, burada kastedilenin bütün mümkün varlıkların kendisine dayandığ1 tam illet olduğundan dolayı O'nun varlığının hiçbir şeye muhtaç olmadığını vurgulamaktadır. Fakat illetten kastedilen müstakil fâil illet olduğunda ise durum farklıdır. Çünkü Devvânî, fâil illet ile hem metafizik hem de varlık hiyerarşisi içinde bulunan fâili, başka bir ifadeyle tabiî düzlemdekini kastetmektedir. Zira Devvânî, birlik (vahdaniyet) mertebesinin sadece Vâcibü'l-Vücûd'a özgü olduğunu ve bütün varlıkların da nihayetinde O'na dayandığını açıkça ifade etmektedir. Oysa mümkün olan fâil illetin diğer varlıkların var olmasında herhangi bir tesiri söz konusu değildir. Onlar sadece vasita konumundadır. Buradan hareketle Devvânî, bütün varlıkların hiyerarşik bir düzen oluşturduğunu düşünülürse ya doğrudan ya da vasıtalı bir şekilde Vâcib'e dayandığını ileri sürmektedir. ${ }^{86}$ Onun "Mümkün varlıkların Vâcib'e dayanması ya başlangıç ya da vasita iledir."87 İfadesi ise Fârâbî ve İbn Sînâ'nın ortaya koyduğu ve sistemleştirdiği sudûr nazariyesini kabul ettiği kanaatine neden olmaktadır.

Devvânî'nin Allah'in varlığını zorunlu (vücûb) oluşundan hareketle de ispatlamaya çalıştığı göze çarpmaktadır. Ona göre Allah'ın varlığ kendisi üzerine eklenti değildir. Aksine O, kendine özel varlığ1

85 Tam illet, "Kendisi yanında ma'lûlünün varlığı vâcip olan şeydir.”; Nâkıs illet ise "Tam illetin aksidir." Cürcânî, Kitâbü't-Ta'rîfât, s. 190.

86 Devvânî, Risâletü İsbâti'l-vâcibi'l-cedîde, s. 122; Fâil illetin metafizikte ve tabiî düzlemde farklılaştığı fikrinin temelini esas itibariyle İbn Sînâ'da bulabiliriz. İbn Sînâ, Metafizik, II, s. 1-2.

87 Devvânî, Risâletü İsbâti'l-vâcibi'l-cedîde, s. 122. 
(vücûd) ile özdeştir. O, Allah'in zorunluluğunun (vücûb) delilini şu şekilde açıklar:

"Eğer O'nun varlığ1 zât1 üzerine zâit olsayd1 O mevcûd olduğu halde bitişen (telif) olurdu. Meselâ, bu konuda ispatlandığı gibi, ma'dûm olmaz ve mevcûd olduğu halde ilinekler (arazlar) göz önüne alınmaksızın O'nun zâtının tanımı olmaz. Bu şekilde olan her şey ise mümkündür. Çünkü onun varlık ile nitelenmesi, ya onun zât1 sebebiyledir ki bu muhaldir, zira şey, var olmadıkça var olmaz. Böylece varlığı zâtını öncelemesi gerekir. Bu ise saçmadır. Ya da varlık ile nitelenmesi başkası sebebiyle olur. Bu durumda da o, ma'lûl olur, vâcip olmaz." 88

Devvânî, illiyet ile zorunluluğun aynı anlamda olduğunu söylemekte ve Farabî ve İbn Sînâ'da olduğu gibi, Vâcibü'l-Vücûd'un varlığında hiçbir sebep olmadığını O'nun zorunlu oluşundan hareketle açıklamaktadır. Çünkü Devvânî’ye göre varlığı için zorunlu olduğunun söylenmesi sakıncalıdır. O, Vâcip Varlık’ın zorunlu oluşunu imkân kavramından hareketle açıklar. Zira ona göre, imkânın yokluğu ya zâta göre ya da O'nun dişındakilere göredir. Zâta göre olmasında zât, kendisine göre yokluğun imkânsızlı̆̆ manasında illettir. İkinci durumda, yani başkasına göre ise onun başkasına muhtaç olmasını gerektirir. Başkasına muhtaç olan varlığın ise zorunlu (vâcip) olduğu düşünülemez. Hâlbuki Vâcip Teâlâ zâtıyla kâim, zâtında bütün bağ (nisb) ve i'tibarlardan mücerred olarak Sirf Varlık'tır (ez-Zâtü'l-Baht). ${ }^{89}$

Vâcip Teâlâ'nın varlığında hiçbir şey muhtaç olmayıp, Sırf Varlık olduğunu tespit ettikten sonra Devvânî, O'nun birliğinin ispatı konusuna geçer. Allah'in birliği ile ilgili Devvânî, iki aşamalı bir yol takip eder. Birinci aşama; eğer vâcip varlık çok olsaydı, bu çok vâcip varlıklar birbirlerinden ya zât bakımından ayrılırlar ya da onların birbirlerinden farkı zâtları üzerine zâit bir durum olurdu. Birinci durumda Vâcibü'l-Vücûd mefhumu arazî bir yüklemle bütün

88 Devvânî, Risâletü İsbâti'l-vâcibi'l-cedîde, s. 124.

89 Devvânî, Risâletü İsbâti'l-vâcibi'l-Cedîde, s. 124-125; krş. Fârâbî, Kitâbu Ârâu ehlil-medîneti'l-fâzıla, s. 39; İbn Sînâ, İşaretler ve Tembihler, s. 127. 
vâcip varlıklar üzerine yüklenmiş olur. Arız ise arâz için ma'lûldür. $\mathrm{Bu}$ durum da vâcip varlıkların hepsinin, varlığı zorunlu olan için illet olmasını gerektirir. Bu ise muhaldir. İkincisi, yani vâcip varlıkların birbirlerinden farklı olması durumu, söz konusu farkın onların zâtı bakımından değil de eklenti bir şey ile olacağından dolayı saçmadır. Buradan itibaren Allah'ın birliğinin ispatı noktasında ikinci aşamaya geçen Devvânî, vâcip varlığın çok olması durumunda ya onun hey'eti ya da diğerleri için ma'lûl olacağını söylemektedir. Birincisi, yani hey'et olması durumda vâcip varlıkların mahiyetinin birliği gerekir. Eğer onların mahiyetinin birliği söz konusu olursa bu durumda Vâcip Varlık müşterek bir anlam olarak ortaya çıkmış olur. $\mathrm{Bu}$ ise saçmadır. Eğer mahiyet çok olursa, bu durumda da onların hepsi varlığı zorunlu olan için araz bir şey olur. Oysa varlık (vücûd), vâcip için kesindir (müekket). Dolayısıyla Vâcibü'l-Vücûd söz konusu olduğunda varlık zâtına eklenti değil, zâtındandır. İkincisinde, yani başkasına ma'lûl olmasında ise başkasına ve imkâna muhtaç olması durumu ortaya çıkar. Başkasına ve imkâna muhtaç olan bir varlık ise vâcip değil, mümkün olur. ${ }^{90} \mathrm{Bu}$ noktada İbn Sînâ'nın et-Ta'lîkât ${ }^{91}$ adlı eserine atıf yapan Devvânî, Vâcibü'lVücûd'un hüviyetinin tek olduğunu söylemektedir. Başka bir ifadeyle, O'nun mevcûd olarak var olması varlığının kendisidir. O'nun zorunluluğu muhtelif çokluk üzerine yüklemle bölünemez. Çünkü yüklem olması durumunda O, ma'lûl olur. Hâlbuki Vâcibü'lVücûd'un varlığı başkası için değil, sadece kendisi içindir. ${ }^{92}$

Görüldüğü üzere Devvânî, "bir" ve "vücûb" kavramlarından hareketle Vâcibü'l-Vücûd'un zâtının hiçbir şekilde çokluğu kabul etmeyen tek bir hakikat olduğunu vurgulamaktadır. Devvânî, bir

90 Devvânî, Risâletü İsbâti'l-vâcibi'l-cedîde, s. 125.

91 İbn Sînâ, et-Ta'lîkât, s. 26, 28, 37, 61.

92 Devvânî, Risâletü İsbâti'l-vâcibi'l-cedîde, s. 127; Devvânî, burada İbn Kemmûne'nin (ö.683/1284) eserinde zikrettiği delillere atıf yapar, ancak ayrıntısını vermekten kaçınmıştır. İbn Kemmûne el-Cedîd fi'l-hikme adlı eserinde Vâcibü'l-Vücûd'un birliğini altı başlıkta ele alır. Bk. İbn Kemmûne, elCedîd fi'l-hikme, nşr. Hamid Mer’id Kübeysi, Bağdad: Câmiatu Bağdad, 1982, s. 535-542; Fatma Zehra Pattabanoğlu, İbn Kemmûne Felsefesi, Ankara: Elis Yayınları, 2014, s. 86-90. 
başka şekilde, "O olması belirginleşen mevcûddur." ifadesiyle de Vâcip Teâlâ'nın kendine özel bir varlığa sahip olduğuna işaret eder. Vâcibü'l-Vücûd'un varlığı zâtının aynıdır ve zâtıyla var olan varlığın kendisidir. ${ }^{93}$ Devvânî, Vâcip Teâlâ'nın birliğini iki zorunlu hüviyetin olamayacağ düşüncesinden hareketle açıklar. Şayet zâtı için zorunlu ve zâtıyla var olan iki hüviyet olsa, varlığın zorunluluğu ikisi arasinda müşterek bir durum olur ki, bu ise muhaldir. Vâcip Teâlâ'nın birliğini Kur'ân-1 Kerîm'den, "Eğer yerde ve gökte Allah'tan başka ilahlar olsaydı kesinlikle ikisinin de düzeni bozulurdu."94 mealdeki ayeti delil getirerek açıklayan Devvânî̀ye göre eğer zorunlu varlık çok olsaydı iki tane olurdu. Eğer iki zorunlu varlık, zorunluluğu paylaşmış olsalar, bu iki zorunlunun hakikatinin birbirinden bir noktada ayrılması gerekir. Bu durumda her ikisine de söz konusu zorunlu niteliğini verebilecek dışarıdan bir sebebe muhtaç olmaları gerekecektir. Şayet mezkûr sebep, onların zâtlarını öncelerse bu durumda sebebin zorunlu varlık olması gerekir. Zira akıl, bir şeye varlık verenin önce olmasına hükmeder. Oysa Vâcip Teâlâ'nın kendi hakikatinin dışında bir şey olması imkânsızdır. Benzer şekilde kendi hakikatinden bir parçayı veya zorunlu niteliğini başka bir zorunlu ile paylaşması mümkün görünmemektedir. Bunun neticesinde de O'nun tek bir zât ve hakikat olduğu ortaya çıkmaktadır. ${ }^{95}$

Devvânî'nin hem Vâcip Teâlâ'nın varlığı hem de birliğini ispatıyla ilgili ele aldığı bir başka mesele ise varlık-mahiyet ilişkisidir. Konuyla ilgili Devvânî'nin temel referans noktası yine İbn Sînâ'dır. İbn Sînâ, varlığı kendinden olan Zorunlu Varlık için varlık ile mahiyet ayrımını mümkün görmezken, mümkün varlık için varlık ile mahiyetin ayrı olduğunu söylemektedir. Ona göre mümkün varlıklarda

93 Devvânî, Risâletü İsbâti'l-vâcibi'l-cedîde, s. 127, 132.

94 el-Enbiya 21/22.

95 Devvânî, Risâletü İsbâti'l-vâcibi'l-cedîde, s. 134-136; Devvânî'nin Zorunlu Varlık'ın birliği hakkında Risâletü İsbâti'l-vâcibi'l-cedîde'de ortaya koyduğu düşüncelerini Şevâkilü'l-hûr fì Şerhi Heyâkili'n-nûr adlı eserinde de söylemektedir. Nitekim burada iki zorunlu varlık olamayacağı fikrinden hareketle Vâcibü'l-Vücûd'un tek olması gerektiği sonucuna gitmektedir. Bk. Celâleddîn ed-Devvânî, "Şevâkilü'l-hûr fì Şerhi Heyâkili'n-nûr", s. 165; Eyüp Bekiryazıc1, a.g.e., s. 68-69. 
varlık mahiyete sonradan eklenmiştir. ${ }^{96}$ Çünkü varlık ve yokluğa eşit mesafede olan mümkün varlık, var olabilmek için bir illete muhtaçtır. Başka bir ifadeyle mümkün varlık, bilkuvve hem var olma hem de yok olma (ma'dûm) konumundadır. Bilfiil var olma durumuna çıkabilmek için de bilfiil var olan İlk İlke'ye muhtaçtır. Buna karşılık Vâcip Teâlâ'nın ise varlığından başka mahiyeti yoktur (lâ mâhiyetün lehû sivâ'l-vücûd). O, mahiyeti itibariyle var değildir, aksine O, bilfiil vardır. ${ }^{97}$ Eğer Vâcip Teâlâ'da varlık ile mahiyet ayrımı söz konusu olsa, O’nda bilkuvve durumun ve zâtının çokluğu söz konusu olur. Hâlbuki Vâcip Teâlâ tek bir varlıktır. ${ }^{98}$ Varlıkmahiyet ilişkisi tartışmasında Devvânî'nin İbn Sînâ'nın düşüncesini takip ettiği görülmektedir. Ancak onun mümkün varlıklarda varlık ile mahiyet ayrımı konusunda İbn Sînâ'nın düşüncesi ile İşrâkî filozofların görüşlerini birleştirdiği şeklinde bir fikir ileri sürülmüştür. Devvânî, diş dünyada "vücûd" şeklinde isimlendirilen bir şeyin var olmadığını ve aklın tahlil yaparak "vücûd" olarak adlandırılan şeyi ortaya koyduğunu belirtmektedir. $\mathrm{O}$, diş gerçeklikte vücûdun somut bir hüviyetle özdeş olduğu düşüncesine sahiptir. Zira ona göre vücûdun somut bir hüviyetten veya zâttan soyutlanması, Zeyd'den insanlığın soyutlanması gibidir. "Zeyd'de insanlık mahiyeti sabittir." hükmü ancak Zeyd'in zâtı ile geçerlilik kazanabilir. Zira mezkûr hükmün doğruluğu ve geçerliliği, ancak onun diş gerçeklikte karş1lık bulacağı veya uygulanabileceği bir şeyin var olmasına bağlıdır. Ayrıca burada Devvânî'nin vücûd ile zâttan çıkarılan şey arasında bir ayrım yaptığı da dikkat çekmektedir. Ona göre zât hakkında düşünmek, zâtî şeylerin çıkarılabilmesi için yeterlidir. Fakat vücûdun soyutlanmasında hem bir şeyin sebebinin ve sonuçlarının var olması hem de zâttan başka bir şeyin düşünülmesi gerekir. Devvânî'nin mümkün varlıklarda varlık-mahiyet ayrımı hakkında yaptığı açıklamaları keyfi olarak değerlendiren Kemalpaşazâde, ak-

96 İbn Sînâ, Metafizik, I, s. 36-37; a. mlf., İşaretler ve Tembihler, s. 131; Devvânî'nin filozoflara atıf yaptığı görülmektedir. Devvânî, Risâletü İsbâti'tvâcibi'l-cedîde, s. 139.

97 Devvânî, Risâletü İsbâti'l-vâcibi'l-cedîde, s. 139.

98 Devvânî, Risâletü İsbâti'l-vâcibi'l-cedîde, s. 127. 
lın tahlil yaparak "vücûd" şeklinde adlandırılabilecek bir şeyi ç1karmasını Meşşâî filozofların ilkesine, vücûd ile zâtî şeyler arasında bir farkın olduğunu iddia etmesini de İşrâkî filozofların ilkesine dayandırdığını söylemektedir. Bu bağlamda Kemalpaşazâde, Devvânî'nin yaptığı gibi varlık sorununa ilişkin böyle bir problemi iki ilkeye dayandırarak çözüme kavuşturulamayacağını belirtmektedir. ${ }^{99}$ Ancak Devvânî'nin varlık-mahiyet ilişkisi probleminde iki ilkeye dayanarak açıklamasının sadece mümkün varlıklarla ilgili olup, Vâcib Teâlâ hakkında olmadığının belirtilmesi gerekir. Çünkü Risâletü İsbâti'l-vâcibi'l-cedîde'de mümkün varlıklar hakkında, "Bütün mümkünler mahiyetlerdir." ve Vâcib Teâlâ için de, "Zâtından ayrı bir mahiyet yoktur."100 sseklinde açıkça ifadeler kullanması, onun yaklaşımı hakkında net bilgi sahibi olmamızı sağlamaktadır.

Hem kelamcıların hudûs delilini hem de filozofların imkân delilini birlikte kullanan Devvânî'nin eserinde ana hatlarını verdiği isbât1 vâcib ile ilgili akıl yürütmesini her iki risalesini de göz önünde bulundurarak şu şekilde formüle edebiliriz:

1. Varlık vardır.

2. Varlık ya zorunludur ya da mümkündür.

3. Varlıklar silsilesinde zorunlu bir varlık fikrine ulaşılırsa amaç gerçekleşmiştir.

4. Varlık silsilesinde bir zorunlu varlığın mevcut olduğu kabul edilmese geriye sadece mümkün varlıklar kalır.

5. Mümkün varlık, varlık ve yokluğa eşit mesafededir ve bu yüzden de kendi kendine var olamaz. Onun var olabilmesi için bir sebebe ihtiyacı vardır.

99 Mehmet Aydın, "İbn Kemal Paşa'da Varlığın Mahiyete Zait Oluşu: Cürcânî ve Devvânî̀nin Görüşlerinin Eleştirisi”, 38. ICANAS Uluslararası Asya ve Kuzey Afrika Çalışmaları Kongresi, Eylül 2007, Ankara: Atatürk Kültür, Dil ve Tarih Yüksek Kurumu Yayınları, 2008, s. 32-33; Devvânînin zikredilen ikili yaklaŞımı Şerhu Risâleti'z-Zevrâ'da görülebilir. Bk. Celâleddîn ed-Devvânî, Şerhu Risâleti'z-Zevrâ, Seb'u Resâil içinde, nşr. Seyyid Ahmed Toyserkanî, Tahran, 2002, s. 206-208.

100 Bk. Devvânî, Risâletü İsbâti'l-vâcibi'l-cedîde, s. 139. 
6. Bu sebep ise ya mümkün varlıklardan oluşan bütünün bireylerinden her biridir ya bu bireylerden bir kısmıdır ya da bütünün dışında başka bir şeydir.

7. Sebep, bireylerden her biri olamaz; bu bütünün kendi kendinin sebebi olduğu manasına gelir; bir şeyin ise hem sebep hem de sonuç olması imkânsızdır.

8. Sebep, bütünün bir kısmı da olamaz; çünkü bütünden bazıları diğer bazıları için sebep olma önceliğine sahip değildir.

9. Öyleyse mümkün varlıklardan oluşan bütün, var olabilmek için kendileri dişından birine muhtaçtır. Bu sebep ise varlığı kendinden olan Vâcibü'l-Vücûd'dan başkası değildir. ${ }^{101}$

Böylece ortaya çıkmaktadır ki, Devvânî'nin düşünce dünyasında varlığın var olduğu hakkındaki bilgi kesindir (bedîhî) ve var olan mevcutlar içinde her şeyin İlke'si olan bir zorunlu varlık vardır, hatta O'nun var olması zorunludur. Çünkü Vâcib Varlık'n var olmaması durumunda mümkün varlık asla var olamaz. Bu ise Vâcib Varlık olan Allah'in yok farzedilmesi durumunda varlığının da yok olacağı manası taşımaktadır. Devvânî'nin ifadesiyle söylersek, "Zorunlu yoksa varlık da yoktur (lem yecib lem yûced)." Devvânî, Vâcibül-Vücûd'un yokluğunu imkânsız görmekte ve O'nun isbâtına da yokluğunun imkânsızlığını göstererek başlamaktadır. Esasında burada varlığın bilgisini kesin kabul eden Devvânî, varlık silsilesinde bir Zorunlu Varlık'in mevcut olmasını zorunlu görmektedir. Çünkü Zorunlu Varlık kabul edilmediği takdirde mümkün varlıkların da var olmasından söz edilemez. Bu ise mümkün varlıkların Zorunlu Varlık'ın delili değil, Zorunlu Varlık'ın varlığının mümkün varlıkla-

101 Devvânî'nin isbat-1 vâcibe ilişkin görüşlerinin formülü şeklinde sunduğumuz bu akıl yürütme, gerçekte İbn Sînâ'nın isbât-1 vâcib konusundaki akıl yürütmesinin formülüdür. Her ne kadar Devvânî, bu şekilde kapsamlı bir formül sunmasa da temel öncüllerini zikrettiği görülmektedir (Devvânî, a.g.e., s. 134-135). Varlık analizinde İbn Sînâ'nın varlık anlayışına çok yakın bir yaklașım sergileyen Devvânî'nin de isbât-1 vâcip hakkında yazmıș olduğu her iki risalesini göz önüne aldığımızda aynı formülün kullanabileceği kanaatindeyiz. Mezkûr akıl yürütme formülün geçtiği kaynaklar hakkında bk. Engin Erdem, "İbn Sînâ'nın Metafizik Delili", s. 105. 
rın varlığ için bir delil olduğu sonucuna ulaştırmaktadır. ${ }^{102}$ Yukarıda Devvânî'nin bu yaklaşımın burhân-ı innî olduğunu söylemiştik. Dolayısıyla Devvânî'nin benzer yaklaşım sergilediği İbn Sînâ'nın varlık teorisi çerçevesinde zorunlu ile mümkün arasındaki ilişkiyi dikkate alırsak zorunlunun varlığ mümkün ile değil, mümkünün varlığı zorunlu ile açıklanmaktadır. Çünkü İbn Sînâ felsefesinde mümkün varlık, sadece varlığa gelebilmek için değil, yokluk mertebesinde de zorunlu varlığa muhtaçtır. Dolayısıyla mümkün âlemin var olabilmesi için İlk İlke olan Vâcibü'l-Vücûd'un varlığı zorunludur.

Risâletü İsbâti'l-vâcibi'l-cedîde adlı eseri boyunca Allah'ı tanımayı amaçlayan Devvânî'nin, mezkûr eserinde üzerinde durduğu ikinci husus, Allah'ın sifatları konusudur. Sifatlar meselesi İslâm düşüncesinde filozoflar ile kelâmcılar arasında en çok tartışılan konulardan biridir. Sifatların Allah'a nispeti konusunda Eş'ârî kelâmcıları sıfatları O'nun zâtına zâid olarak düşünmüşler ve O'nun bir ilimle âlim, bir kudretle kâdir olduğunu söylemişlerdir. Filozoflar ise sifatları zâtının aynı kabul ederek Allah'n zâtıyla âlim ve zâtıyla kâdir olduğunu ifade etmişlerdir. ${ }^{103}$ Devvânî ise zat-sıfat ilişkisi ile ilgili olarak Vâcip Teâlâ'nın zâtı için değişen hakiki sıfatlarının olmadığını belirtmektedir. Çünkü O'nda zâtı ile sıfat ayrımı söz konusu olsa, O ilim sıfatıyla âlim, kudret sifatıyla kâdir ve irade sifatıyla mürîd olacaktır. Bu durumda da O, bu sıfatlar için hem fâil hem de kâbil olacaktır. Oysa hakiki bâsit olan Allah'in bir şey için hem fâil hem de kâbil olması imkânsızdır. O, maddeden ve onun ilineklerinden mücerred olması bakımından en yücedir. Dolayısıyla Allah, başkasıyla değil, zâtıyla var olduğundan kendisi için ilimdir. Böylece de $\mathrm{O}$, ilim, âlim ve ma'lümdür. Devvânî’nin Allah'n sıfatları hakkındaki bölümünün başında da, "Allah'ın sıfatları zâtının aynıdır." ifadesin-

\footnotetext{
102 Devvânî, Risâletü İsbâti'l-vâcibi'l-cedîde, s. 118-119.

103 Cürcânî, Şerhu'l-Mevâkıf, III, s. 66, 68; Gazzâlî, İtikadda Orta Yol, s. 115; Taftazânî, Şerhu'l-Akâid, haz. Süleyman Uludağ, İstanbul: Dergâh Yayınları, 1999, s. 157.
} 
den zât-sıfat ilişkisi problemine filozoflar gibi bir yaklaşım sergilediği açıkça görülmektedir. ${ }^{104}$

Devvânî'nin mezkûr eserinde mârifetullah ile ilgili olarak üzerinde durduğu üçüncü nokta da âlemin mükemmelliğidir. O, eserin son kısminda "Allah'ın Hikmeti" ve "Allah'ın Cömertliği" başlıklarında âlemin mükemmelliğinden hareketle Allah'ın varlığının isbâtını yapmaktadır. Devvânî, âlemin mükemmelliğini Allah'ın ilim ve kudret sıfatlarından hareketle açıklamaktadır. Ona göre Allah, cehalete benzemeyen en mükemmel bir ilim ve acziyetin bulaşmadığ en kâmil bir kudret ile vasıflanmıştır. Devvânî, âlemin mükemmelliğini Allah'ın sanatı olarak ifade etmekte ve O'nun sanatının akılların bir nebze yakalamakta tereddüt ettiği en ince hikmetleri kapsadığını vurgulamaktadır. O, ayrıca astronomi (hey'et) ve anatominin (teşrîh) özelleştiği sanatlara bakışla onların sanat olarak değerlendirilmesi gibi, âlemin de Allah'in bir sanatı olduğunu söylemektedir. Ancak Allah, âlimlerin en âlimi, hâkimlerin en hâkimi ve kâdirlerin de en kâdiridir. Hatta O'nun ilmine nispetle âlimlerin ilmî cehalet bile sayılabilir. ${ }^{105}$ Devvânî'nin bu düşüncelerinden âlemdeki harikulade ahengin temel ilkesi olarak Allah'ın ilmini gördügü anlaşılmaktadır. Ancak ona göre âlemin olabilecek en mükemmel bir tarzda var olması Allah'ın ulaşmak istediği bir gaye ile değildir. Aksine âlemin varlık sebebi, Allah'ın inâyeti ve dolayısıyla cömertliğidir (cûd). Devvânî, cömertliği "herhangi bir karşıllk beklenmeyen şey"106 olarak tanımlamakta ve bu anlamda İbn Sînâ gibi, hakiki cömertin

104 Devvânî, Risâletü İsbâti'l-vâcibi'l-cedîde, s. 140; krș. İbn Sînâ, "Tevhîdin Hakikati ve Nübüvvetin İspat1 Üzerine", İslâm Filozoflarından Felsefe Metinleri içinde, trc. Mahmut Kaya, İstanbul: Klasik Yayınları, 2003, s. 313.

105 Devvânî, Risâletü İsbâti'l-vâcibi'l-cedîde, s. 167.

106 İbn Sînâ, cömertliği karşılıksız vermek şeklinde tanımlamaktadır. Ona göre gerçek cömertlik, herhangi bir karşılık beklemeksizin yapılan iyiliktir. Bu anlamda karşılık beklenerek yapılan birtakım iyilikler cömertlik sayılmamaktadır. Filozof, eserinde gerçek/hakiki cömert ile mecazî cömert arasında bir ayrım yapmakta ve gerçek cömerti, kişinin kendisine dönecek herhangi bir istek ve arzu olmadan faydaların ortaya çıkması şeklinde tanımlamaktadır. Bu anlamda gerçek cömert herhangi bir gayesi olmayan Mahzâ İyi olan Vâcibü'l-Vücûd'dur. Bk. İbn Sînâ, Metafizik, II, s. 122; a. mlf., İşaretler ve Tembihler, s. 144-145. 
sadece Allah olabileceğini ifade etmektedir. Allah'ın dişındakiler ise fiillerinde herhangi bir şekilde karşıllk beklediğinden hakiki cömert olarak kabul edilmemektedir. İyilikler, Allah'tan herhangi bir karş1lık beklenmeksizin mümkün varlıklar üzerine feyzeder. Bu çerçevede bazı mümkünlerde görülen kötülük veya noksanlık kabilinden fiillerin ${ }^{107}$ ise Devvânî, Allah'ın cimriliğinden dolayı değil, aksine kabul edenin eksikliği sebebiyle olduğunu söylemektedir. Âlemdeki kötülüğün varlığının sebebi olarak onun eksikliğine vurgu yapan Devvânî, bu düşüncesini bazı Kur'an-1 Kerîm ayetleriyle destekler. Çünkü ona göre Allah, her türlü yetkinliğin sahibidir, kudreti ve hikmeti tamdır ve O'nun fiillerinde hiçbir şekilde eksiklik yoktur. Dolayısıyla âlem, en mükemmel bir düzen ile O'nun ilmine ve hikmetine uygun bir şekilde var olmuştur. ${ }^{108}$

Görüldüğü üzere Devvânî, en mükemmel bir düzen ile âlemin var olmasının ilkesinin Allah'in hikmeti olduğunu söylemekle, âlemin var olma ilkesi olarak Allah'ın varlığı olduğu gibi, âlemin mükemmelliğinin ilkesinin de yine O olduğunu vurgulamaktadır. Dolayısıyla Devvânî'nin düşüncesinde hem müessirden esere hem de eserden müessire gidilsin yine de âlemin mükemmel bir şekilde var olma ve varlığını sürdürmede ilkesi sadece Vâcib Varlık olan Allah’tır.

\section{Sonuç}

İslâm metafizik düşüncesinin en önemli problemlerinden biri olan isbât-1 vâcib meselesi, hem farklı ilmî disiplinlere mensûb düşünürler tarafindan tartışılmış hem de oldukça zengin bir literatürde ele alınmıștır. Allah'ın varlığının ispatıyla ilgili filozoflar imkân,

107 Devvânî, Şevâkilü'l-Hûr fî şerhi Heyâkili'n-nûr adlı eserinde bizzât kötülük olarak âlemde az miktarda bulunan kötülüğün kaynağı olarak Allah'ı göstermiştir. Ancak bu az miktarda var olan kötülük ise gerçekte ona bağlı olarak gerçekleșen Allah'ın lütuf ve iyiliklerine bağlamıștır. Bk. Devvânî, Şevâkilü'l-Hûr fî şerhi heyâkili'n-nûr, s. 114; Eyüb Bekiryazıcı, a.g.e., s. 160.

108 Devvânî, Risâletü İsbâti'l-vâcibi'l-cedîde, s.167-168; Devvânî, Allah'ın hikmeti ile ilgili olarak Fârâbî'nin et-Ta'lîkât adlı eserindeki bir pasajı aynen tekrar eder. Krş. Fârâbî, et-Ta'lîkât, s. 46. 
kelamcılar ise hudûs delilini ileri sürmüşlerdir. İmkân ve hudûs delilleri Gazzâlî öncesi dönemde farklı düşünce ekollerinde tartış1lırken ilk defa her iki delil Şehristânî tarafından mezcedilerek kullanılmış ve daha sonra Fahreddin er-Râzî ve Necmeddin Kâtibî gibi düşünürler tarafından da yeniden formüle edilerek sonraki nesillere intikal etmiştir. Mezkûr deliller ayrıca devr ve teselsülün geçersizliği düşüncesinden hareketle de tartışılmıştır. Ancak Kâtibî, Cürcânî ve Devvânî gibi bazı düşünürler de imkân ve hudûs delilleriyle devr ve teselsüle dayanmaksızın Allah'ın varlığının isbatının yapılabileceğini dile getirmişlerdir.

İsbât-1 vâcib konusunda biri gençliğinde, diğeri ileri yaşlarında iki risale yazan Devvânî, birincisinde Allah'ın varlığının isbatıyla ilgili istidlâl yolları ve imkânını ele almıs, ikincisinde de konu hakkındaki görüşlerini ikmâl etmiştir. O, İbn Sînâ'da olduğu gibi, "Varlık vardır." önermesinden hareketle, varlık analiziyle başladığı ispat yönteminde Allah'ın varlığında hiçbir şeye muhtaç olmadığını, buna karşılık O'nun dışındaki bütün varlıkların var olmada ve varlığını sürdürmede O'na muhtaç oldukları sonucuna ulaşmıştır. Devvânî, Risâletü İsbâti'l-vâcibi'l-cedîde adlı eserinde Allah'in varlığı hakkında getirilen her delilin nihayetinde innî olduğunu söyleyerek hem burhân-ı innîyi hem de burhân-ı limmîyi kullanarak bir ispat yapmaktadır. Başka bir ifadeyle o, Vâcibü'l-Vücûd'u merkeze alarak, Müessir'den esere giden bir yöntemle, Allah'ın varlığını diğer varlıkların var olmasının şartı olarak görmüştür. Allah'ın varlığının ispatında aklî delili kullanan Devvânî, Allah'ın birliğini ispatlamada naklî ve müşahede yöntemlerini kullanmış ve O'nun birliğini (vahdaniyetini) iki zorunlu varlık olamayacağı düşüncesinden hareketle ispatlamıştır. Allah'ın zâtından ayrı bir mahiyetinin olmayacağı düşüncesinde olan Devvânî, âlemde mükemmel bir düzenin olduğunu ve bu mükemmelliğin ilkesinin de Zorunlu Varlık olan Allah'ın cömertliği ve hikmeti olduğunu belirtmektedir.

Sonuç olarak, isbât-1 vâcibe ilişkin telif ettiği Risâletü İsbâti'lvâcibi'l-cedîde adlı eserinde Fârâbî ve İbn Sînâ'ya yapmış olduğu atıfları göz önünde bulundurursak, Devvânî̀nin konuyla ilgili Meşşâî filozofların görüşlerinin etkisinde olduğu, ancak "bu yol, kelam- 
c1ların metodundan belirlenip seçilmiştir" ifadesiyle de kelamcıların görüşlerini de göz ardı etmediği söylenebilir. Hatta onun mârifetullah ve varlık problemine yaklaşımının İslâm düşünce geleneğinde konuyla ilgili ortaya çıkan önemli görüşlerin genel analizi olarak değerlendirmek mümkündür. Bu sebeple de Devvânî'nin isbât-1 vâcib problemine dair yazdığ1 mezkûr eserleri, yaşadığ 1 dönemden önce konuya ilişkin ortaya konulan düşüncelerin özümsenerek, analitik ve tenkitçi bir üslubla değerlendirilmesini içerdiğinden dolayı İslâm düşünce geleneği içinde önemi haiz bir kıymet taşıdığı belirtilmelidir.

\section{BİBLIYYOGRAFYA}

Ahmed Nuri, İsbât-ı Vâcib, S.K. Yazma Bağışlar böl., no: 3129.

Alper, Ömer Mahir, “İbn Sînâ'da Tanrı'nın Kanıtlanması Sorunu: O Gerçekten Kelâmcilardan Etkilendi mi?” İ.Ü. Ilahiyat Fakültesi Dergisi, Say1 VII, Y11 2003, İstanbul 2003, s. 61-77.

Alper, Ömer Mahir, İslâm Felsefesinde Akıl-Vahiy/Felsefe-Din İlişkisi, İstanbul: Ayışığı Kitapevi, 2000.

Alper, Ömer Mahir, Varlık ve İnsan Kemalpaşazâde Bağlamında Bir Tasavvurun Yeniden İnşası, İstanbul: Klasik Yayınları, 2010.

Altaş, Eşref, Fahreddin er-Râzînin İbn Sînâ Yorumu ve Eleştirisi, İstanbul: İz Yayıncılık, 2009.

Anay, Harun, "Devvânî", DİA, IX, İstanbul 1994, s. 257-261.

Anay, Harun, "Mîr Giyâseddin Mansûr" DİA, XXX, İstanbul 2005, s. 125-128.

Alpyağıl, Recep, Gelen-eksel ve Çağdaş Metinlerle Din Felsefesine Dair Okumalar, I, İstanbul: İz Yayınc1lık, 2011.

Arıc1, Mustakim, Necmettin el-Katibi ve Metafizik Düşüncesi, (Bası1mamış Doktora Tezi), İ.Ü. Sosyal Bilimler Enstitüsü, İstanbul, 2011.

Aydın, Mehmet, "İbn Kemal Paşa'da Varlığın Mahiyete Zait Oluşu: Cürcânî ve Devvânî'nin Görüşlerinin Eleştirisi”, 38. ICANAS Uluslararası Asya ve Kuzey Afrika Çalışmaları Kongresi, Eylül 
2007, Ankara: Atatürk Kültür, Dil ve Tarih Yüksek Kurumu Yayınlar1, 2008, s. 25-38.

Aydın, Hüseyin, Ebu'l-Hasen el-Eş'ârî'de Nazar ve İstidlâl, Ankara, Fecr Yayınları, 2012.

Bâkillânî, Ebû Bekr Muhammed b. Tayyib b. Muhammed Basri, elİnsâf, nşr. İmadüddin Ahmed Haydar, Beyrut: Âlemü'1-Kütüb, 1986.

Bekiryazıcı, Eyüp, Devvânî Felsefesinin Ontolojik Temelleri, Ankara: Araştırma Yayınları, 2009.

Beyazîzade Ahmed Efendi, İmam-ı A'zam Ebû Hanîfe'nin İtikadî Görüşleri (el-Usûlü'l-münîfe li'l-imam Ebû Hanîfe), trc. İlyas Çelebi, İstanbul: İFAV Yayınları, 2000.

el-Cürcânî, Seyyid Şerîf, Kitâbü't-Ta'rîfât, Beyrut: Mektebetü'lLübnân, 1985.

el-Cürcânî, Seyyid Şerîf, Şerhu'l-Mevâkıf, I-III, nşr. Abdurrahman Umeyra, Beyrut: Dârü'l-Cil, 1997.

el-Cürcânî, Seyyid Şerîf, Şerhu'l-Mevâkıf, I, trc. Ömer Türker, İstanbul: Kırk Gece Yayınları, 2011.

el-Cüveynî, İmâmü'l-Haremeyn, el-Burhân fî usûli'l-fikh, I, nşr. Abdülazîm ed-Dîb, Devha: Câmiatu Katar, 1399/1978.

el-Cüveynî, İmâmü'l-Haremeyn, İnanç Esasları Kılavuzu, trc. Adnan Bülent Baloğlu vd., Ankara: Türkiye Diyanet Vakfı Yayınları, 2010.

el-Cüveynî, İmâmü'l-Haremeyn, Kitâbü'l-İrşâd ilâ kavâtii'l-edille fî usûli'l-i'tikad, nşr. Esad Temim, Beyrut: Müessesetü'l-Kütübi'sSekafiye, 1985.

Demir, Osman, "Kelâm'da Teselsülü İptali Delilleri ve İsmail Hakkı İzmirli'nin Teselsül Risâlesi”, İslâm Araştırmaları Dergisi, Sayı 23, 2010, s. 117-142.

Demirkol, Murat, "Kâtibî ve Tûsî'de Tanrı'nın Varlığını Zincirlemenin İptali Yoluyla İspatlama”, Kelam Araştırmaları, 9:2, (2011), s. 92-130.

Descartes, Metod Üzerine Konuşmalar, trc. Mehmet Karasan, Ankara: Milli Eğitim Bakanlığı Yayınları, 1997. 
ed-Devvânî, Celâleddîn, "Şevâkilü'l-hûr fî Şerhi Heyâkili'n-nûr", Selâsü Resâil içinde, Meşhed: Mecmaü'l-Buhusi'l-İslâmiyye, 1991, s. 105-256.

ed-Devvânî, Celâleddîn, Risâletü İsbâti'l-vâcibi'l-kadîme, Seb'u Resâil içinde, nşr. Ahmed Tuysirkani, Tahran: Merkez-i Neşr-i Miras-1 Mektub, 2002, s. 69-113.

ed-Devvânî, Celâleddîn, Risâletü İsbâti'l-vâcibi'l-cedîde, Seb'u Resâil içinde, nşr. Ahmed Tuysirkani, Tahran: Merkez-i Neşr-i Miras-1 Mektub, 2002, s. 117-170

ed-Devvânî, Celâleddîn, Şerhu Risâleti'z-Zevrâ, Seb'u Resâil içinde, nşr. Seyyid Ahmed Toyserkanî, Tahran, 2002, s. 199-227.

Doru, Nesim, “İbn-i Arabi'nin Fahreddin Razi'ye Gönderdiği Mektup”, Dicle Üniversitesi Ilahiyat Fakültesi Dergisi, C. IV, Sayı 1, Y11 2002, s. 99-105.

Erdem, Engin, “ỉbn Sînâ'nın Metafizik Delili”, Ankara Üniversitesi İlahiyat Fakültesi Dergisi, 52:1 (2011), s. 97-119.

Erdem, Engin, "Ahmed Nuri: İbn Sînâ’nın İsbât-1 Vâcib Yöntemi”, Dini Araştırmalar, C. XIV, Sayı XXXIX, Y11 2011, s. 50-69.

Fârâbî, "Felsefenin Temel Meseleleri (Uyûnü'l-mesâil)", İslâm Filozoflarından Felsefe Metinleri içinde, İstanbul: Klasik Yayınları, 2005.

Farabi, et-Ta'likkât, nşr. Cafer Al-i Yasin, Beyrut: Dârü'l-Menâhil, 1988.

Fârâbî, Kitâbu's-Siyâseti'l-medeniyye, nşr. Fevzi Mitri Neccâr, Beyrut: Dâru'l-meşr1k, 1993.

Gazzâlî, el-Maksadü'l-esnâ fî şerhi Esmâillâhi'l-hüsnâ, thk. Fadlou A. Shehadi, Beyrut 1971.

Gazzâlî, İtikadda Orta Yol, (el-İktisâd fi'l-'itikâd), nşr. ve trc. Osman Demir, İstanbul: Klasik Yayınları, 2012.

Gazzâlî, Mişkâtü'l-envâr ve misfâtü'l-esrar, nşr. Abdülaziz İzzeddin es-Seyrevan, Beyrut: Âlemü'l-Kütüp, 1986.

Hanoğlu, İsmail, Râzî Düşüncesinde Felsefenin Temel Disiplinleri ve Pozitif Bilimler, Ankara: Araştırma Yayınları, 2014. 
İbn Fûrek, Mücerred Makâlati'ş-Şeyh Ebi'l-Hasan el-Eş'ârî, nşr. Daniel Gimaret, Beyrut: Dârü'l-Maşrık, 1986.

İbn Kemmûne, el-Cedîd fi'l-hikme, nşr. Hamid Mer'id Kübeysi, Bağdad: Câmiatu Bağdad, 1982.

İbn Rüşd, Faslü'l-makal, nşr. ve trc. Bekir Karlığa, İstanbul: İşaret Yayınlar1, 1999.

İbn Sînâ, "Tevhîdin Hakikati ve Nübüvvetin İspatı Üzerine", İslâm Filozoflarindan Felsefe Metinleri içinde, trc. Mahmut Kaya, İstanbul: Klasik Yayınları, 2003.

İbn Sînâ, et-Ta'lîkât, nşr. Abdurrahman Bedevî, Kum: Mektebetü'lI'lami'l-İslâmî, 1984.

İbn Sînâ, İşaretler ve Tembihler, (el-İşârât ve't-Tenbîhât), nşr. ve trc. Ali Durusoy-Muhittin Macit-Ekrem Demirli, İstanbul: Litera Yayınc1l1k, 2005.

İbn Sînâ, Kitâbü'n-Necât, nşr. Mâcid Fahrî, Beyrut: Dârü'l-Âfâki'lCedide, 1985.

İbn Sînâ, Kitâbu'ş-Şifâ: II. Analitikler, nşr. ve trc. Ömer Türker, İstanbul: Litera Yayınc1lik, 2006.

İbn Sinnâ, Metafizik, I, nşr. ve trc. Ekrem Demirli-Ömer Türker, İstanbul: Litera Yayınc1lik, 2004.

İbn Sînâ, Metafizik, II, nşr. ve trc. Ekrem Demirli-Ömer Türker, İstanbul: Litera Yayınc1lik, 2005.

İskenderoğlu, Muammer, "Fahreddin er-Râzî'de İsbât-1 Vâcib ve Tanr1-Âlem İlişkisi”, İslâm Düşüncesinin Dönüşüm Çağında Fahreddin er-Râzî içinde, (ed. Ömer Türker-Osman Demir), İstanbul: İSAM Yayınlar1, 2013, s. 473-504.

Kâdî Abdülcebbâr, Mu'tezile'nin Beş İlkesi (SSerhu'l-usûli'l-hamse), I, nşr. ve trc. İlyas Çelebi, İstanbul: Türkiye Yazma Eserler Kurumu başkanlığı Yayınları, 2013.

Kâdî Beyzâvî, Kelâm Metafiziği (Tavâli'u'l-Envâr), nşr. ve trc. İlyas Çelebi-Mahmut Çınar, İstanbul: Türkiye Yazma Eserler Kurumu Başkanlığı Yayınları, 2014.

Kemalpaşazâde, Risâle fì İsbâti'l-vâcib, S.K. Kılıç Ali Paşa Böl., no: $568 / 6$. 
Kutluer, İlhan, İbn Sînâ Ontolojisinde Zorunlu Varlı, İstanbul: İz Yayınc1lik, 2002.

Mîr Sadreddîn eş-Şîrâzî, fî̀ İsbâti'l-Bârî Teâlâ ve sıfatihi'l-husnâ, S.K. Çorlulu Ali Paşa Böl., no: 304, vr. 126b-142 b.

Muhammed Ekrem Ebû Gûş, "Risâletü İsbâti'l-vâcib li-İmâmi'dDevvânî”, Mecmû' Selâse Resâil içinde, Amman: Dârü'n-Nûr elMübîn, 2013, s. 55-196.

Nasîreddîn et-Tûsî, Şerhu'l-İşârât ve't-Tenbîhât, III, nşr. Süleyman Dünya, Beyrut: Müessesetü'n-Numan, 1993.

Özervarl1, M. Sait, "İsbât-1 Vâcib", DİA, XXII, İstanbul 2000, s. 495497.

Pattabanoğlu, Fatma Zehra, İbn Kemmûne Felsefesi, Ankara: Elis Yayınları, 2014.

Râzî, Fahreddin, el-Mebâhisü'l-meşrikıyye, fì 'ilmi'l-ilâhiyyât ve'ttabîiyyât, I, nşr. M.M. el-Bağdâdî, Bayrut: Dârü'l-Kitâbi'l-Arabî, 1990.

Râzî, Fahreddin, el-Metâlibü'l-âliye mine'l-ilmi'l-ilâhî, I, nşr. A. Hicâzî es-Sekkâ, Beyrut: Dârül-kütübil-Arabî,1987.

Şehristânî, Kitâbu'l-Musâraa (Filozoflarla Mücadele), nşr. ve trc. Aygün Akyol-Aytekin Özel, İstanbul: Litera Yayınc1lık, 2010.

Şehristânî, Nihâyetü'l-ikdâm fî ilmi'l-kelâm, nşr. Alfred Guillaume, London: (y.y.), 1934.

Taftazânî, Şerhu'l-Akâid, haz. Süleyman Uludağ, İstanbul: Dergâh Yayınlar1, 1999.

Teftâzânî, Şerhu'l-Makâsıd, I, nşr. Abdurrahman Umeyra, Beyrut: Âlemül-Kütüp, 1998.

Topaloğlu, Bekir, İslâm Kelâmcıları ve Filozoflarına Göre Allah'ın Varlığı (İsbât-ı Vâcib), Ankara: Diyanet İşleri Başkanlığı Yayınlar1, (tsz).

Türker, Ömer, "Kelâm ve Felsefe Tarihinde Fahreddin er-Râzî", İslâm Düşüncesinin Dönüşüm Çağında Fahreddin er-Râzî içinde, (ed. Ömer Türker-Osman Demir), İstanbul: İSAM Yayınları, 2013, s. $17-40$ 